\title{
G Research SGuare $=0$ \\ Impact of the COVID-19 pandemic on the epidemiology of out-of-hospital cardiac arrest: A systematic review and meta-analysis
}

\section{Seth En Teoh}

National University of Singapore Faculty of Medicine: National University Singapore Yong Loo Lin

School of Medicine

\section{Yoshio Masuda}

National University Singapore Yong Loo Lin School of Medicine

\section{Darren Jun Hao Tan}

NUS Yong Loo Lin School of Medicine: National University Singapore Yong Loo Lin School of Medicine

Nan Liu

Duke-NUS: Duke-NUS Medical School

\section{Laurie J. Morrison}

St Michael's Hospital Li Ka Shing Knowledge Institute

\section{Marcus Eng Hock Ong}

Singapore General Hospital

\section{Audrey L. Blewer}

DUMC: Duke University School of Medicine

Andrew Fu Wah Ho ( $\square$ andrew.ho@duke-nus.edu.sg)

Singapore General Hospital https://orcid.org/0000-0003-4338-3876

\section{Research}

Keywords: cardiac arrest, COVID-19, pandemic, coronavirus, emergency medical services, resuscitation, ambulance, sudden cardiac death, out of hospital, OHCA, epidemiology

Posted Date: August 20th, 2021

DOI: https://doi.org/10.21203/rs.3.rs-788944/v1

License: (c) (i) This work is licensed under a Creative Commons Attribution 4.0 International License. Read Full License

Version of Record: A version of this preprint was published at Annals of Intensive Care on December 1st, 2021. See the published version at https://doi.org/10.1186/s13613-021-00957-8. 


\section{Abstract \\ Background}

The coronavirus disease 2019 (COVID-19) pandemic has significantly influenced epidemiology, yet its impact on out-of-hospital cardiac arrest (OHCA) remains unclear. We aimed to evaluate the impact of the pandemic on the incidence and case fatality rate (CFR) of OHCA. We also evaluated the impact on intermediate outcomes and clinical characteristics.

\section{Methods}

PubMed, EMBASE, Web of Science, Scopus, and Cochrane Library databases were searched from inception to May 3,2021 . Studies were included if they compared OHCA processes and outcomes between the pandemic and historical control time periods. Meta-analyses were performed for primary outcomes (annual incidence, mortality, and case fatality rate [CFR]), secondary outcomes (field termination of resuscitation [TOR], return of spontaneous circulation [ROSC]), survival to hospital admission, and survival to hospital discharge), and clinical characteristics (shockable rhythm and etiologies). This study was registered in the International Prospective Register of Systematic Reviews (PROSPERO) (CRD42021253879).

\section{Results}

The COVID-19 pandemic was associated with a 39.5\% increase in pooled annual OHCA incidence $(p<$ 0.001). Pooled CFR was increased by $2.65 \%$ ( $p<0.001)$, with a pooled odds ratio (OR) of 1.95 for mortality $(95 \%$ confidence interval $[95 \% \mathrm{Cl}] 1.51-2.51)$. There was increased field TOR $(O R=2.46,95 \% \mathrm{Cl}$ $1.62-3.74)$. There were decreased ROSC $(O R=0.65,95 \% \mathrm{Cl} 0.55-0.77)$, survival to hospital admission $(\mathrm{OR}=0.65,95 \% \mathrm{Cl} 0.48-0.89)$, and survival to discharge $(\mathrm{OR}=0.52,95 \% \mathrm{Cl} 0.40-0.69)$. There was decreased shockable rhythm $(\mathrm{OR}=0.73,95 \% \mathrm{Cl} 0.60-0.88)$ and increased asphyxial etiology of $\mathrm{OHCA}$ $(\mathrm{OR}=1.17,95 \% \mathrm{Cl} 1.02-1.33)$.

\section{Conclusion}

Compared to the pre-pandemic period, the COVID-19 pandemic period was significantly associated with increased OHCA incidence and worse outcomes.

\section{Introduction}

The coronavirus disease 2019 (COVID-19) pandemic, caused by the emergent novel severe acute respiratory syndrome coronavirus 2 (SARS-CoV-2), ${ }^{1}$ has had a far-reaching public health impact of global 
proportions. ${ }^{2}$ This has influenced the epidemiology of important diseases, ${ }^{3}$ not only through the direct impact of COVID-19 infections, but also through indirect effects on health services delivery, access to care, and health-seeking behaviors.

In particular, the impact of the pandemic on out-of-hospital cardiac arrest (OHCA) epidemiology is of tremendous public health and scientific interest. ${ }^{4}$ Not only does OHCA exert a large disease burden in many communities, its care processes also reflect the efficient integration of bystander care, ambulance care, and hospital care within health systems. ${ }^{5} \mathrm{~A}$ growing body of anecdotal and scientific reports from some parts of the world have suggested that the COVID-19 pandemic was associated with changes in incidence, care processes, and clinical outcomes. For example, a population-based observational study in Paris, France, reported that the maximum weekly OHCA incidence had nearly doubled from 13.42 to 26.64 per million population during the pandemic period (March-April, 2020) compared to the pre-pandemic period (March-April, 2012-2019). ${ }^{6}$ However, reports from other parts of the world did not find a similar association. ${ }^{7,8}$

While some of the negative effects of the pandemic on incidence and outcomes were likely mediated through COVID-19 infections (especially OHCA of respiratory nature), ${ }^{9,10}$ it is likely that there are multifactorial drivers of these trends. These may include the interruption of primary care for chronic diseases, reduced willingness to seek early treatment for acute symptoms leading to increased risk of OHCA, as well as worsened prognosis due to less efficient bystander, ambulance, and hospital interventions for OHCA. ${ }^{11-15}$ These treatment processes may have, in turn, been adversely affected by reduced bystander willingness to render life-saving interventions, ${ }^{16,17}$ altered airway management protocols, ${ }^{18}$ or even overwhelmed healthcare facilities. ${ }^{19}$

Accordingly, the aim of this study was to evaluate the impact of the COVID-19 pandemic on the incidence, characteristics, and clinical outcomes of OHCA through a systematic review and meta-analysis. We primarily hypothesized that compared to the pre-pandemic period, the COVID-19 pandemic period was associated with increased incidence and case fatality rate (CFR) of OHCA. We further postulated that the rates of intermediate clinical outcomes (return of spontaneous circulation [ROSC], survival to hospital admission, and survival to hospital discharge) decreased during the pandemic. Finally, we postulated that there was a change in the etiologies of OHCA during the pandemic as well as a decline in the rate of shockable rhythm as the initial presenting rhythm. A consolidated understanding of the impact of the COVID-19 pandemic on OHCA epidemiology will inform future pandemic preparedness and response strategies.

\section{Methods}

This systematic review and meta-analysis adhered to the Preferred Reporting Items for Systematic Reviews and Meta-Analyses (PRISMA) guidelines. ${ }^{20}$ It was registered in the International Prospective Register of Systematic Reviews (PROSPERO) (CRD42021253879). 


\subsection{Search Strategy}

The search strategy was developed in consultation with a medical information specialist. We utilized the MeSH term "heart arrest" and the non-MeSH terms "sudden cardiac arrest, sudden cardiac death, out of hospital cardiac arrest, out-of-hospital cardiac arrest, cardiac arrest, OHCA, OOHCA, covid-19, coronavirus, and SARS-CoV-2" (Appendix I). We performed a literature search with these search terms in five bibliographic databases from inception to May 3, 2021: PubMed, EMBASE, Web of Science, Scopus, and The Cochrane Central Register of Controlled Trials (CENTRAL) in The Cochrane Library. References of relevant sources were hand-searched to identify additional relevant studies.

\subsection{Selection Criteria}

All studies were filtered through the following inclusion criteria: $(A)$ patients with OHCA during the COVID19 pandemic and $(B)$ articles that reported any of the following outcomes and clinical characteristics: incidence of OHCA, mortality, field TOR, ROSC, survival to hospital admission, survival to hospital discharge, shockable rhythm, and etiology of OHCA.

The exclusion criteria were: (A) articles not written in the English language, (B) articles that did not utilize a historical control (comparing outcomes prior to and during the pandemic), (C) case reports, and (D) editorials.

The hierarchical selection of titles, abstracts, and full manuscripts was conducted by two independent reviewers, SET and YM. Subsequently, the web-based platform Rayyan QCRI was utilized to deconflict selected articles in a blinded manner. ${ }^{21}$ Disagreements were resolved after consensus with the senior author, AFWH.

\subsection{Data Abstraction and Quality Assessment}

Three authors (SET, YM, and DJHT) independently abstracted data using a predefined spreadsheet (Microsoft Corp, New Mexico, United States). Conflicts with data collection were resolved after consensus with the senior author, AFWH. Study characteristics abstracted included the name of first author, year of publication, country and city of study population, study design, study population, date cut-offs for time periods of (i) pre-COVID-19 and (ii) COVID-19, and sample sizes for time periods of (i) pre-COVID-19 and (ii) COVID-19. Moreover, we abstracted patient characteristics including age, percentage who were male, percentage with shockable rhythm, and percentage with different etiologies of OHCA, namely medical, traumatic, drowning, overdose, and asphyxial. Lastly, we abstracted outcomes data: incidence, mortality, field TOR, ROSC, survival to hospital admission, and survival to hospital discharge. If data were unclear, we contacted the corresponding author of the publication via email for further clarification.

The Newcastle-Ottawa Scale ${ }^{22}$ was used by two independent reviewers (SET and YM) to evaluate the risk of bias within the included studies. ${ }^{6-8,23-39}$ The scale included eight items, and possible scores ranged from 0 to 9 . Studies with a score of seven or more were considered high quality. 


\subsection{Calculation of Annual OHCA Incidence}

Incidence estimates were abstracted only from studies that used a population-based data source, allowing the inference of population parameters. Where studies did not directly report incidence, we manually computed incidence if the studies provided data on case counts and the corresponding population-at-risk (i.e. coverage of the data source). This assumed that population-at-risk remained constant over the study period, and that each unique person could contribute only one OHCA episode. We used the reference period of each respective study to standardize these to annual incidence per 100000 population. Incidence estimates of individual communities were weighted and averaged according to the size of the population-at-risk. This approach was previously utilized by Berdowski et al in a systematic review of OHCA incidence. ${ }^{40}$

\subsection{Statistical Analysis}

Data analyses were performed using the meta 4.18-0 and metafor 2.4-0 packages in R 3.6.3 (R Foundation for Statistical Computing, Vienna, Austria). Meta-analyses of proportions were conducted for the outcomes of annual OHCA incidence and CFR. Meta-analyses were performed for the characteristics: shockable rhythm and etiologies of OHCA (medical, traumatic, and asphyxial) and outcomes: mortality, field TOR, ROSC, survival to hospital admission, and survival to hospital discharge.

In the meta-analyses of proportions, data for the outcomes of annual OHCA incidence and CFR were transformed using the Freeman-Tukey double arcsine method. ${ }^{41}$ The transformed data were then pooled through an inverse variance methodology, before back-transformation into normalized proportions. The DerSimonian-Laird estimator was used as our between-study variance estimator, and a random-effects model was employed to estimate the pooled study estimates due to marked study heterogeneity. Results were then presented in forest plots, with relevant outcomes reported as proportions with $95 \%$ confidence intervals $(95 \% \mathrm{Cl})$. Comparisons between the outcomes of annual OHCA incidence and CFR for pre-COVID19 and COVID-19 periods were performed with two-proportions z-tests. Box plots were used to represent these results.

For other outcomes, fixed- and random-effects models were used in conjunction with the Sidik-Jonkman estimator and Mantel-Haenszel method to estimate the pooled effects of COVID-19, depending on the presence of substantial between-study heterogeneity. Forest plots displayed pooled odds ratios (OR) and $95 \% \mathrm{Cl}$ for mortality, field TOR, ROSC, survival to hospital admission, survival to hospital discharge, shockable rhythm, and etiologies of OHCA. Two-tailed statistical significance was set at $p$-value $\leq 0.05$. The $\mathrm{I}^{2}$ statistic was used to quantify statistical heterogeneity. ${ }^{42}$ Whenever there was substantial statistical heterogeneity $\left(I^{2}>50 \%\right)$, we evaluated for outliers by performing a set of case deletion diagnostics to identify influential studies and subsequent leave-one-out sensitivity analyses. Publication bias was evaluated via visual evaluation of funnel plots and Egger's regression.

\section{Results}




\subsection{Literature Retrieval}

The database search yielded 966 articles. After removal of duplicates, 546 articles were screened on the basis of their abstracts. After screening, 122 papers were sought for retrieval, of which 14 articles could not be retrieved. The resultant 108 full-texts were reviewed, and 20 identified as meeting the selection criteria. The study selection process and reasons for excluding the 88 excluded studies were illustrated in the PRISMA-P 2020 Flow Diagram (Fig. 1).

\subsection{Characteristics of Studies and Risk of Bias}

The included studies originated from 10 countries (Australia, France, Italy, Korea, Singapore, Spain, Sweden, The Netherlands, United Kingdom, and United States of America). All studies were retrospective in study design.

There were a total of 67815 patients included in the 20 studies, comprising 38855 patients in the preCOVID-19 period and 28960 patients in the COVID-19 period. Study sample sizes ranged from 101 to 19303 patients. Study characteristics and the summary of overall findings were summarized in Table 1 and Table 2 respectively. 
Table 1

Characteristics of Included Studies

\begin{tabular}{|c|c|c|c|c|c|}
\hline Study & Location & $\begin{array}{l}\text { Study } \\
\text { Design\# }\end{array}$ & Study Population & $\begin{array}{l}\text { Time Period } \\
\text { (i) Pre- } \\
\text { COVID-19ll } \\
\text { (ii) COVID- } \\
\text { 19ll }\end{array}$ & $\begin{array}{l}\text { Sample } \\
\text { Size } \\
\text { (i) Pre- } \\
\text { CoVID- } \\
19 l l \\
\text { (ii) } \\
\text { COVID- } \\
19 \text { ll }\end{array}$ \\
\hline $\begin{array}{l}\text { Baert et } \\
\text { al, } \\
2020^{23}\end{array}$ & France & $\begin{array}{l}\text { Registry- } \\
\text { based } \\
\text { study }\end{array}$ & $\begin{array}{l}\text { Adult and pediatric cases } \\
\text { of presumed medical } \\
\text { etiology (EMS*-treated } \\
\text { NR§; Received } \\
\text { resuscitation NRß) }\end{array}$ & $\begin{array}{l}\text { (i) March } 1 \text { - } \\
\text { April 31, } \\
2019 \\
\text { (ii) March } 1 \\
\text { - April 31, } \\
2020\end{array}$ & $\begin{array}{l}\text { (i) } \\
1620 \\
\text { (ii) } \\
1005\end{array}$ \\
\hline $\begin{array}{l}\text { Baldi et } \\
\text { al, } \\
2020^{24}\end{array}$ & Lombardy, Italy & $\begin{array}{l}\text { Registry- } \\
\text { based } \\
\text { study }\end{array}$ & $\begin{array}{l}\text { Adult and pediatric cases } \\
\text { regardless of etiology } \\
\text { (EMS'-treated NRß; } \\
\text { Received resuscitation } \\
\text { NRß) }\end{array}$ & $\begin{array}{l}\text { (i) February } \\
21-\text { April 20, } \\
2019 \\
\text { (ii) February } \\
21-\text { April 20, } \\
2020\end{array}$ & $\begin{array}{l}\text { (i) } 321 \\
\text { (ii) } 490\end{array}$ \\
\hline $\begin{array}{l}\text { Ball et al, } \\
2020^{7}\end{array}$ & Victoria, Australia & $\begin{array}{l}\text { Registry- } \\
\text { based } \\
\text { study }\end{array}$ & $\begin{array}{l}\text { Adult cases regardless of } \\
\text { etiology; EMS E-treated and } \\
\text { received resuscitation }\end{array}$ & $\begin{array}{l}\text { (i) March } 16 \\
\text { - May 12, } \\
2017-2019 \\
\text { (ii) March } 16 \\
\text { - May 12, } \\
2020\end{array}$ & $\begin{array}{l}\text { (i) } \\
1218 \\
\text { (ii) } 380\end{array}$ \\
\hline $\begin{array}{l}\text { Cho et al, } \\
2020^{25}\end{array}$ & $\begin{array}{l}\text { Daegu, South } \\
\text { Korea }\end{array}$ & $\begin{array}{l}\text { Registry- } \\
\text { based } \\
\text { study }\end{array}$ & $\begin{array}{l}\text { Adult cases of presumed } \\
\text { medical etiology; EMS* } \\
\text { treated and received } \\
\text { resuscitation }\end{array}$ & $\begin{array}{l}\text { (i) February } \\
17-\text { March } \\
31,2018 \\
\text { (ii) February } \\
17-\text { March } \\
31,2020\end{array}$ & $\begin{array}{l}\text { (i) } 158 \\
\text { (ii) } 171\end{array}$ \\
\hline $\begin{array}{l}\text { Elmer et } \\
\text { al, } \\
2020^{26}\end{array}$ & $\begin{array}{l}\text { Pennsylvania, } \\
\text { USA }^{\ddagger}\end{array}$ & $\begin{array}{l}\text { Registry- } \\
\text { based } \\
\text { study }\end{array}$ & $\begin{array}{l}\text { Adult cases regardless of } \\
\text { etiology; } \text { EMS }^{\star} \text {-treated } \\
\text { (Received resuscitation } \\
\text { NR§) }\end{array}$ & $\begin{array}{l}\text { (i) January - } \\
\text { February } \\
2016-2020 \\
\text { (ii) March } 1 \\
\text { - May 25, } \\
2020\end{array}$ & $\begin{array}{l}\text { (i) } \\
12252 \\
\text { (ii) } 683\end{array}$ \\
\hline
\end{tabular}

${ }^{\star} E M S$, Emergency Medical Services; ${ }^{\dagger} U K$, United Kingdom; ${ }^{\ddagger} U S A$, United States of America; $§ N R$, Not Reported; "COVID-19, coronavirus disease 2019; \#Study designs for all included studies were multicentred and retrospective in nature 


\begin{tabular}{|c|c|c|c|c|c|}
\hline Study & Location & $\begin{array}{l}\text { Study } \\
\text { Design\# }\end{array}$ & Study Population & $\begin{array}{l}\text { Time Period } \\
\text { (i) Pre- } \\
\text { COVID-19ll } \\
\text { (ii) COVID- } \\
\text { 19l| }\end{array}$ & $\begin{array}{l}\text { Sample } \\
\text { Size } \\
\text { (i) Pre- } \\
\text { CoVID- } \\
19 \| \\
\\
\text { (ii) } \\
\text { COVID- } \\
19 l\end{array}$ \\
\hline $\begin{array}{l}\text { Lai et al, } \\
2020^{27}\end{array}$ & $\begin{array}{l}\text { New York City, } \\
\text { USA }^{\ddagger}\end{array}$ & $\begin{array}{l}\text { Non- } \\
\text { registry- } \\
\text { based } \\
\text { study }\end{array}$ & $\begin{array}{l}\text { Adult cases regardless of } \\
\text { etiology; EMS }{ }^{\star} \text {-treated and } \\
\text { received resuscitation }\end{array}$ & $\begin{array}{l}\text { (i) March } 1 \text { - } \\
\text { April 25, } \\
2019 \\
\text { (ii) March } 1 \\
\text { - April 25, } \\
2020\end{array}$ & $\begin{array}{l}\text { (i) } \\
1336 \\
\text { (ii) } \\
3989\end{array}$ \\
\hline $\begin{array}{l}\text { Marijon } \\
\text { et al, } \\
2020^{6}\end{array}$ & Paris, France & $\begin{array}{l}\text { Registry- } \\
\text { based } \\
\text { study }\end{array}$ & $\begin{array}{l}\text { Adult cases of non- } \\
\text { traumatic etiology; EMS*- } \\
\text { treated (Received } \\
\text { resuscitation NR§) }\end{array}$ & $\begin{array}{l}\text { (i) Weeks } \\
12-17 \text {, } \\
2012-2019 \\
\text { (ii) March } 16 \\
\text { - April 26, } \\
2020\end{array}$ & $\begin{array}{l}\text { (i) } \\
3052 \\
\text { (ii) } 521\end{array}$ \\
\hline $\begin{array}{l}\text { Ortiz et } \\
\text { al, } \\
2020^{28}\end{array}$ & Spain & $\begin{array}{l}\text { Registry- } \\
\text { based } \\
\text { study }\end{array}$ & $\begin{array}{l}\text { Adult and pediatric cases } \\
\text { regardless of etiology; } \\
\text { EMS }^{*} \text {-treated (Received } \\
\text { resuscitation NR§) }\end{array}$ & $\begin{array}{l}\text { (i) April 1- } \\
30,2017 \text { and } \\
\text { February } 1- \\
\text { March 31, } \\
2018 \\
\text { (ii) February } \\
1-\text { April } 30 \text {, } \\
2020\end{array}$ & $\begin{array}{l}\text { (i) } \\
1723 \\
\text { (ii) } \\
1446\end{array}$ \\
\hline $\begin{array}{l}\text { Paoli et } \\
\text { al, } \\
2020^{29}\end{array}$ & $\begin{array}{l}\text { Province of } \\
\text { Padua, Italy }\end{array}$ & $\begin{array}{l}\text { Non- } \\
\text { registry- } \\
\text { based } \\
\text { study }\end{array}$ & $\begin{array}{l}\text { Adult and pediatric cases } \\
\text { regardless of etiology; } \\
\text { EMS*-treated (Received } \\
\text { resuscitation NR } \$ \text { ) }\end{array}$ & $\begin{array}{l}\text { (i) March } 1 \text { - } \\
\text { April 30, } \\
2019 \\
\text { (ii) March } 1 \\
\text { - April 30, } \\
2020\end{array}$ & $\begin{array}{l}\text { (i) } 206 \\
\text { (ii) } 200\end{array}$ \\
\hline $\begin{array}{l}\text { Sayre et } \\
\text { al, } \\
2020^{30}\end{array}$ & $\begin{array}{l}\text { Seattle and King } \\
\text { County, USA }\end{array}$ & $\begin{array}{l}\text { Registry- } \\
\text { based } \\
\text { study }\end{array}$ & $\begin{array}{l}\text { Adult and pediatric cases } \\
\text { regardless of etiology; } \\
\text { EMS*-treated (Received } \\
\text { resuscitation NR } \text { N }^{\star}\end{array}$ & $\begin{array}{l}\text { (i) January } 1 \\
\text { - February } \\
25,2019 \\
\text { (ii) February } \\
26-\text { April } 15 \text {, } \\
2020\end{array}$ & $\begin{array}{l}\text { (i) } 530 \\
\text { (ii) } 537\end{array}$ \\
\hline
\end{tabular}

${ }^{\star} E M S$, Emergency Medical Services; ${ }^{\dagger} U K$, United Kingdom; ${ }^{\ddagger} U S A$, United States of America; $\S_{N R}$, Not Reported; "COVID-19, coronavirus disease 2019; \#Study designs for all included studies were multicentred and retrospective in nature 


\begin{tabular}{|c|c|c|c|c|c|}
\hline Study & Location & $\begin{array}{l}\text { Study } \\
\text { Design\# }\end{array}$ & Study Population & $\begin{array}{l}\text { Time Period } \\
\text { (i) Pre- } \\
\text { COVID-19ll } \\
\text { (ii) COVID- } \\
19^{\| l}\end{array}$ & $\begin{array}{l}\text { Sample } \\
\text { Size } \\
\text { (i) Pre- } \\
\text { COVID- } \\
19^{l l} \\
\text { (ii) } \\
\text { COVID- } \\
19 \| l\end{array}$ \\
\hline $\begin{array}{l}\text { Semeraro } \\
\text { et al, } \\
2020^{31}\end{array}$ & Bologna, Italy & $\begin{array}{l}\text { Registry- } \\
\text { based } \\
\text { study }\end{array}$ & $\begin{array}{l}\text { Adult cases regardless of } \\
\text { etiology; EMS*-treated and } \\
\text { received resuscitation }\end{array}$ & $\begin{array}{l}\text { (i) January } 1 \\
\text { - June 30, } \\
2019 \\
\text { (ii) January } 1 \\
\text { - June 30, } \\
2020\end{array}$ & $\begin{array}{l}\text { (i) } 563 \\
\text { (ii) } 624\end{array}$ \\
\hline $\begin{array}{l}\text { Chan et } \\
\text { al, } \\
2021^{32}\end{array}$ & $\begin{array}{l}27 \text { States and } \\
\text { multiple Counties, } \\
\text { USA }^{\ddagger}\end{array}$ & $\begin{array}{l}\text { Registry- } \\
\text { based } \\
\text { study }\end{array}$ & $\begin{array}{l}\text { Adult cases of non- } \\
\text { traumatic etiology; EMS*- } \\
\text { treated (Received } \\
\text { resuscitation NRß) }\end{array}$ & $\begin{array}{l}\text { (i) March } 16 \\
\text { - April 30, } \\
2019 \\
\text { (ii) March } 16 \\
\text { - April 30, } \\
2020\end{array}$ & $\begin{array}{l}\text { (i) } \\
9440 \\
\text { (ii) } \\
9863\end{array}$ \\
\hline $\begin{array}{l}\text { de } \\
\text { Koning et } \\
\text { al, } \\
2021^{33}\end{array}$ & $\begin{array}{l}\text { Hollands-Midden, } \\
\text { The Netherlands }\end{array}$ & $\begin{array}{l}\text { Registry- } \\
\text { based } \\
\text { study }\end{array}$ & $\begin{array}{l}\text { Adult cases regardless of } \\
\text { etiology; EMS }{ }^{\star} \text {-treated } \\
\text { (Received resuscitation } \\
\text { NRß) }\end{array}$ & $\begin{array}{l}\text { (i) March } 16 \\
\text { - April 27, } \\
2019 \\
\text { (ii) March } 16 \\
\text { - April 27, } \\
2020\end{array}$ & $\begin{array}{l}\text { (i) } 45 \\
\text { (ii) } 56\end{array}$ \\
\hline $\begin{array}{l}\text { Fothergill } \\
\text { et al, } \\
2021^{8}\end{array}$ & London, $\mathrm{UK}^{\dagger}$ & $\begin{array}{l}\text { Registry- } \\
\text { based } \\
\text { study }\end{array}$ & $\begin{array}{l}\text { Adult and pediatric cases } \\
\text { regardless of etiology; } \\
\text { EMS }^{*} \text {-treated (Received } \\
\text { resuscitation NR } \text { S }^{-}\end{array}$ & $\begin{array}{l}\text { (i) March } 1 \text { - } \\
\text { April 30, } \\
2019 \\
\text { (ii) March } 1 \\
\text { - April 30, } \\
2020\end{array}$ & $\begin{array}{l}\text { (i) } \\
1724 \\
\text { (ii) } \\
3122\end{array}$ \\
\hline $\begin{array}{l}\text { Glober et } \\
\text { al, } \\
2021^{34}\end{array}$ & $\begin{array}{l}\text { Indiana (Marion } \\
\text { County), USA }{ }^{\ddagger}\end{array}$ & $\begin{array}{l}\text { Registry- } \\
\text { based } \\
\text { study }\end{array}$ & $\begin{array}{l}\text { Adult cases of non- } \\
\text { traumatic etiology; EMS*- } \\
\text { treated (Received } \\
\text { resuscitation NR }\end{array}$ & $\begin{array}{l}\text { (i) January } 1 \\
\text { - June 30, } \\
2019 \\
\text { (ii) January } 1 \\
\text { - June 30, } \\
2020\end{array}$ & $\begin{array}{l}\text { (i) } 884 \\
\text { (ii) } \\
1034\end{array}$ \\
\hline
\end{tabular}

${ }^{\star} E M S$, Emergency Medical Services; ${ }^{\dagger} U K$, United Kingdom; ${ }^{\ddagger} U S A$, United States of America; $§ N R$, Not Reported; "COVID-19, coronavirus disease 2019; \#Study designs for all included studies were multicentred and retrospective in nature 


\begin{tabular}{|c|c|c|c|c|c|}
\hline Study & Location & $\begin{array}{l}\text { Study } \\
\text { Design\# }\end{array}$ & Study Population & $\begin{array}{l}\text { Time Period } \\
\text { (i) Pre- } \\
\text { COVID-19ll } \\
\text { (ii) COVID- } \\
\text { 19ll }\end{array}$ & $\begin{array}{l}\text { Sample } \\
\text { Size } \\
\text { (i) Pre- } \\
\text { CoVID- } \\
19^{\prime l} \\
\\
\text { (ii) } \\
\text { CoVID- } \\
19 l\end{array}$ \\
\hline $\begin{array}{l}\text { Lim et al, } \\
2021^{35}\end{array}$ & Singapore & $\begin{array}{l}\text { Registry- } \\
\text { based } \\
\text { study }\end{array}$ & $\begin{array}{l}\text { Adult cases regardless of } \\
\text { etiology; EMS }{ }^{\star} \text {-treated } \\
\text { (Received resuscitation } \\
\text { NRß) }\end{array}$ & $\begin{array}{l}\text { (i) January } 1 \\
\text { - May 31, } \\
2018-2019 \\
\text { (ii) January } 1 \\
\text { - May 31, } \\
2020\end{array}$ & $\begin{array}{l}\text { (i) } \\
1280 \\
\text { (ii) } \\
1400\end{array}$ \\
\hline $\begin{array}{l}\text { Mathew } \\
\text { et al, } \\
2021^{36}\end{array}$ & Detroit, USA ${ }^{\ddagger}$ & $\begin{array}{l}\text { Registry- } \\
\text { based } \\
\text { study }\end{array}$ & $\begin{array}{l}\text { Adult cases of non- } \\
\text { traumatic etiology; EMS*- } \\
\text { treated and received } \\
\text { resuscitation }\end{array}$ & $\begin{array}{l}\text { (i) March } 10 \\
\text { - April 30, } \\
2019 \\
\text { (ii) March } 10 \\
\text { - April 30, } \\
2020\end{array}$ & $\begin{array}{l}\text { (i) } 180 \\
\text { (ii) } 291\end{array}$ \\
\hline $\begin{array}{l}\text { Nickles et } \\
\text { al, } \\
2021^{37}\end{array}$ & $\begin{array}{l}\text { Detroit (Macomb, } \\
\text { Oakland, and } \\
\text { Wayne Counties), } \\
\text { USA }^{\ddagger}\end{array}$ & $\begin{array}{l}\text { Registry- } \\
\text { based } \\
\text { study }\end{array}$ & $\begin{array}{l}\text { Adult and pediatric cases } \\
\text { of non-traumatic etiology; } \\
\text { EMS }{ }^{\star} \text {-treated (Received } \\
\text { resuscitation NR } \mathrm{NR}^{\S} \text { ) }\end{array}$ & $\begin{array}{l}\text { (i) January } 1 \\
- \text { May 31, } \\
2019 \\
\text { (ii) January } 1 \\
\text { - May 31, } \\
2020\end{array}$ & $\begin{array}{l}\text { (i) } \\
1162 \\
\text { (ii) } \\
1854\end{array}$ \\
\hline $\begin{array}{l}\text { Sultanian } \\
\text { et al, } \\
2021^{38}\end{array}$ & Sweden & $\begin{array}{l}\text { Registry- } \\
\text { based } \\
\text { study }\end{array}$ & $\begin{array}{l}\text { Adult and pediatric cases } \\
\text { regardless of etiology; } \\
\text { EMS*-treated and received } \\
\text { resuscitation }\end{array}$ & $\begin{array}{l}\text { (i) January } 1 \\
- \text { March 16, } \\
2020 \\
\text { (ii) March } 16 \\
\text { - July 20, } \\
2020\end{array}$ & $\begin{array}{l}\text { (i) } 930 \\
\text { (ii) } \\
1016\end{array}$ \\
\hline $\begin{array}{l}\text { Uy- } \\
\text { Evanado } \\
\text { et al, } \\
2021^{39}\end{array}$ & $\begin{array}{l}\text { Oregon } \\
\text { (Multnomah } \\
\text { County) and } \\
\text { California } \\
\text { (Ventura County), } \\
\text { USA }^{\ddagger}\end{array}$ & $\begin{array}{l}\text { Registry- } \\
\text { based } \\
\text { study }\end{array}$ & $\begin{array}{l}\text { Adult and pediatric cases } \\
\text { regardless of etiology; } \\
\text { EMS*-treated and received } \\
\text { resuscitation }\end{array}$ & $\begin{array}{l}\text { (i) March } 1 \text { - } \\
\text { May 31, } \\
2019 \\
\text { (ii) March } 1 \\
\text { - May 31, } \\
2020\end{array}$ & $\begin{array}{l}\text { (i) } 231 \\
\text { (ii) } 278\end{array}$ \\
\hline $\begin{array}{l}{ }^{*} E M S, \text { Em } \\
\text { Reported } \\
\text { multicen }\end{array}$ & $\begin{array}{l}\text { cy Medical Ser } \\
\text { ID-19, coronavi }\end{array}$ & $\begin{array}{l}{ }^{\dagger} U K, \mathrm{UI} \\
\text { sease }\end{array}$ & $\begin{array}{l}\text { Kingdom; }{ }^{\ddagger} U S A \text {, United St } \\
{ }^{\#} \text { Study designs for all ino }\end{array}$ & $\begin{array}{l}\text { of America; } \\
\text { ed studies w }\end{array}$ & \\
\hline
\end{tabular}


Table 2

Summary of Overall Findings

\begin{tabular}{|c|c|c|c|c|c|c|}
\hline $\begin{array}{l}\text { OHCAll Outcomes and } \\
\text { Characteristics }\end{array}$ & \multicolumn{2}{|c|}{ Parameters } & $\begin{array}{l}\text { Number of } \\
\text { Studies }\end{array}$ & $\begin{array}{l}\text { Pooled OR } \\
\left(95 \% \mathrm{Cl}^{\dagger}\right)\end{array}$ & $\begin{array}{l}P \\
\text { value }\end{array}$ & $\begin{array}{l}l^{2} \\
\text { Statistic }\end{array}$ \\
\hline \multirow[t]{3}{*}{ Primary Outcomes } & \multicolumn{2}{|c|}{ Annual Incidence } & 10 & $\mathrm{~N} / \mathrm{A}^{\S}$ & $<.001$ & $N / A^{\S}$ \\
\hline & \multicolumn{2}{|c|}{ Case Fatality Rate } & 11 & $N / A \S$ & $<.001$ & $\mathrm{~N} / \mathrm{A}^{\S}$ \\
\hline & \multicolumn{2}{|l|}{ Mortality } & 11 & $\begin{array}{l}1.95(1.51- \\
2.51)\end{array}$ & 0.0002 & $67 \%$ \\
\hline \multirow[t]{4}{*}{ Secondary Outcomes } & \multicolumn{2}{|c|}{$\begin{array}{l}\text { Termination of } \\
\text { Resuscitation }\end{array}$} & 5 & $\begin{array}{l}2.46(1.62- \\
3.74)\end{array}$ & 0.0040 & $93 \%$ \\
\hline & \multicolumn{2}{|l|}{$\mathrm{ROSC}^{*}$} & 15 & $\begin{array}{l}0.65(0.55- \\
0.77)\end{array}$ & $\begin{array}{l}< \\
0.0001\end{array}$ & $85 \%$ \\
\hline & \multicolumn{2}{|c|}{$\begin{array}{l}\text { Survival to Hospital } \\
\text { Admission }\end{array}$} & 10 & $\begin{array}{l}0.65(0.48- \\
0.89)\end{array}$ & 0.0122 & $87 \%$ \\
\hline & \multicolumn{2}{|c|}{$\begin{array}{l}\text { Survival to Hospital } \\
\text { Discharge }\end{array}$} & 11 & $\begin{array}{l}0.52(0.40- \\
0.69)\end{array}$ & 0.0004 & $67 \%$ \\
\hline \multirow[t]{4}{*}{ Characteristics } & \multicolumn{2}{|c|}{ Shockable Rhythm } & 15 & $\begin{array}{l}0.73(0.60- \\
0.88)\end{array}$ & 0.0024 & $70 \%$ \\
\hline & \multirow[t]{3}{*}{ Etiology } & Medical & 9 & $\begin{array}{l}0.91(0.60- \\
1.37)\end{array}$ & 0.5922 & $93 \%$ \\
\hline & & Traumatic & 7 & $\begin{array}{l}0.68(0.41- \\
1.13)\end{array}$ & 0.1108 & $70 \%$ \\
\hline & & Asphyxial & 5 & $\begin{array}{l}1.17(1.02- \\
1.33)\end{array}$ & 0.0317 & $0 \%$ \\
\hline
\end{tabular}

All studies achieved a score ranging from 7 to 9 on the Newcastle-Ottawa Scale, signifying high quality and low risk of bias for selection (Supplemental Table 1).

\subsubsection{Primary Outcomes: Annual OHCA Incidence}

Ten studies reported or provided sufficient data to calculate the annual OHCA incidence (per 100000 population) (Supplemental Table 2). ${ }^{6-8,24,29,30,33-35,37}$ Among them, de Koning et al ${ }^{33}$ reported the lowest annual OHCA incidence of 51 and 63 cases per 100000 population in the pre-COVID-19 and COVID-19 time periods respectively. Meanwhile, Glober et $\mathrm{al}^{34}$ reported the highest annual OHCA incidence of 183 and 214 cases per 100000 population in the pre-COVID-19 and COVID-19 time periods 
respectively. With the exception of Paoli et al ${ }^{29}$, all studies reported a trend of higher annual OHCA incidence during the COVID-19 period compared to the pre-pandemic period.

The meta-analysis of proportions showed an annual OHCA incidence of $0.0860 \%$ or 86.0 cases per 100000 population ( 34511 cases out of 40116274 population) in the pre-COVID- 19 period $(95 \% \mathrm{Cl} 0.07-$ $0.11 \%$ ) with a heterogeneity of $\mathrm{I}^{2}=100 \%, \mathrm{p}<0.01$. In contrast, the annual OHCA incidence was $0.12 \%$ or 121.7 cases per 100000 population ( 48820 cases per 40116274 population) in the COVID-19 period (95\% Cl 0.08-0.15\%) with a heterogeneity of $\mathrm{I}^{2}=100 \%, \mathrm{p}<0.01$ (Figs. 2A-B).

\subsubsection{Primary Outcomes: Mortality and Case Fatality Rate}

Eleven studies provided sufficient data on mortality. ${ }^{6-8,23-25,28,31,32,38,39}$ Mortality ranged from 85.398.4\% across both pre-COVID-19 and COVID-19 time periods. During the pre-COVID-19 period, Uy-Evanado et $\mathrm{al}^{39}$ reported the lowest mortality of $85.3 \%$, while Chan et $\mathrm{al}^{32}$ reported the highest mortality of $96.5 \%$. In contrast, Uy-Evanado et $\mathrm{al}^{39}$ reported the lowest mortality of $92.1 \%$, while Fothergill et $\mathrm{al}^{8} \mathrm{recorded}$ the highest mortality of $98.4 \%$, during the COVID-19 period. Overall, all studies reported higher mortality in the COVID-19 period compared to the pre-pandemic period.

The odds of mortality were significantly higher during the COVID-19 period as compared to the pre-COVID19 period $\left(\mathrm{OR}=1.95,95 \% \mathrm{Cl} 1.51-2.51, \mathrm{p}=0.0002, \mathrm{I}^{2}=67 \%\right)$ (Fig. 3$)$.

A separate meta-analysis of proportions for the outcome of CFR revealed a pooled rate of $93.09 \%$ in the pre-COVID-19 time period (95\% Cl 91.09-94.86\%). Between-study heterogeneity was observed at $\mathrm{I}^{2}=96 \%$, $\mathrm{p}<0.01$. In the COVID-19 period, CFR was $96.38 \%$ (95\%Cl 95.12-97.47\%) with a heterogeneity of $\mathrm{I}^{2}=92 \%$, $\mathrm{p}=<0.01$ (Figs. 2C-D).

3.2.3 Difference in Pooled Estimates of COVID-19 and Pre-COVID-19 Time Periods for Annual OHCA Incidence and Case Fatality Rate

Comparing the pooled estimates for annual OHCA incidence and CFR for pre-COVID-19 and COVID-19 time periods, two-proportions z-tests revealed significant differences between pre-COVID-19 and COVID19 periods for the outcomes of annual OHCA incidence (39.5\% increase, $p<0.001)$ and CFR $(2.65 \%$ increase, $p<0.001$ ), as illustrated in Fig. 4.

\subsubsection{Secondary Outcomes}

\subsubsection{Termination of Resuscitation in the Field}

Five studies reported the outcome of field TOR. $8,24,27,32,36$ The percentage of population experiencing field TOR ranged from 35.6-89.5\% across intervals of the pre-COVID-19 and COVID-19 time periods. All studies reported a trend of higher percentage of patients with field TOR during the COVID-19 period as compared to the pre-pandemic period. 
Meta-analysis showed significantly higher odds of field TOR during the COVID-19 period as compared to the pre-COVID-19 period (OR = 2.46, 95\%Cl 1.62-3.74, $\mathrm{p}=0.0040, \mathrm{I}^{2}=93 \%$ ) (Fig. 5A).

\subsubsection{Return of Spontaneous Circulation}

Fifteen studies reported the outcome of ROSC. 7,8, 23-29,31,32,35,36,38,39 The percentage of population experiencing ROSC ranged from 1.0-41.1\% across intervals of the pre-COVID-19 and COVID-19 time periods. Almost all studies (except Elmer et $\mathrm{al}^{26}$ ) reported a lower percentage of population with ROSC during the pandemic as compared to before the pandemic.

Meta-analysis showed significantly lower odds of ROSC during the COVID-19 time period as compared to the pre-COVID-19 period (OR = 0.65, 95\%Cl 0.55-0.77, p<0.0001, $\mathrm{I}^{2}=85 \%$ ) (Fig. 5B).

\subsubsection{Survival to Hospital Admission}

Ten studies reported the outcome of survival to hospital admission. ${ }^{6,7,25,26,28,29,31,35,36,39}$ With the exception of Elmer et $\mathrm{al}^{26}$ and Paoli et $\mathrm{al}^{29}$, all studies reported a lower percentage of survival to hospital admission in the COVID-19 period relative to during the pre-COVID-19 period.

Meta-analysis showed significantly lower odds of survival to hospital admission in the COVID-19 period as compared to the pre-COVID-19 period (OR $\left.=0.65,95 \% \mathrm{Cl} 0.48-0.89, \mathrm{p}=0.0122, \mathrm{I}^{2}=87 \%\right)(\mathrm{Fig} .5 \mathrm{C})$.

\subsubsection{Survival to Hospital Discharge}

Eleven studies reported the outcome of survival to hospital discharge. ${ }^{6-8,23-25,28,31,32,38,39}$ Almost all studies (except Semeraro et $\mathrm{al}^{31}$ ) reported a lower percentage of survival to hospital discharge in the COVID-19 period relative to during the pre-COVID-19 period.

Meta-analysis showed significantly lower odds of survival to hospital discharge during the COVID-19 period as compared to the pre-COVID-19 period $\left(\mathrm{OR}=0.52,95 \% \mathrm{Cl} 0.40-0.69, \mathrm{p}=0.0004, \mathrm{I}^{2}=67 \%\right)$ (Fig. 5D).

\subsubsection{Clinical Characteristics}

\subsubsection{Shockable Rhythm}

Fifteen studies provided data for the characteristic of shockable rhythm. ${ }^{6-8,23-25,27,28,31-33,35,36,38,39}$ The percentage who had shockable rhythm ranged from 3.6-40\% across intervals of the pre-COVID-19 and COVID-19 time periods. Apart from Semeraro et $\mathrm{al}^{31}$, all studies reported a trend of lower percentage with shockable rhythm in the COVID-19 period as compared to the pre-COVID-19 period.

Meta-analysis showed significantly lower odds of shockable rhythm in the COVID-19 period as compared to the pre-COVID-19 period (OR $=0.73,95 \% \mathrm{Cl} 0.60-0.88, \mathrm{p}=0.0024, \mathrm{I}^{2}=70 \%$ (Fig. $6 \mathrm{~A}$ ).

\subsubsection{Etiology}


Nine ${ }^{7,8,24,26,29,31,32,37,38}$, seven $7,8,24,26,29,31,38$ and five $\mathrm{e}^{7,24,29,32,37}$ studies reported data for medical, traumatic, and asphyxial etiologies of OHCA respectively (Supplemental Table 3). The majority of patients experienced OHCA from medical etiology.

Meta-analysis showed no difference in medical ( $\left.O R=0.91,95 \% \mathrm{Cl} 0.60-1.37, \mathrm{p}=0.592, \mathrm{I}^{2}=93 \%\right)$ and traumatic etiologies $\left(\mathrm{OR}=0.68,95 \% \mathrm{Cl} 0.41-1.13, \mathrm{p}=0.1108, \mathrm{I}^{2}=70 \%\right)$ in both COVID-19 and pre-COVID19 periods. There were significantly higher odds of asphyxial etiology $(\mathrm{OR}=1.17,95 \% \mathrm{Cl} 1.02-1.33, \mathrm{p}=$ $0.0317, \mathrm{I}^{2}=0 \%$ ) for OHCA in the COVID-19 period as compared to the pre-COVID-19 period (Figs. 6B-D). We did not analyze drowning and overdose etiologies of OHCA due to paucity of data.

\subsection{Sensitivity Analyses}

Sensitivity analyses on the influence of outliers were performed as there was substantial statistical heterogeneity observed in almost all outcomes and clinical characteristics (except asphyxial etiology). Potential outliers were first screened on visual inspection of their confidence intervals, followed by influential analyses using influential diagnostic plots and Baujat plots (Supplemental Figs. 2-25). Applying this approach on each clinical characteristic as well as the primary and secondary outcomes, none of the estimates were substantially changed in direction or magnitude, with the exception of survival to hospital admission where the direction was preserved, but the magnitude of effect was increased by $12 \%$. The revised estimates on sensitivity analyses were: mortality $(\mathrm{OR}=1.79[95 \% \mathrm{Cl} 1.46-$ $\left.2.20, p=0.0001, \mathrm{l}^{2}=51 \%\right]$ after excluding Sultanian et a $\left.{ }^{38}\right)$, field TOR $(\mathrm{OR}=2.73[95 \% \mathrm{Cl} 1.67-4.47, \mathrm{p}=$ $\left.0.00074, \mathrm{I}^{2}=65 \%\right]$ after excluding Chan et $\left.\mathrm{a}^{32}\right)$, ROSC $\left(\mathrm{OR}=0.68\left[95 \% \mathrm{Cl} 0.59-0.80, \mathrm{p}=0.0001, \mathrm{I}^{2}=72 \%\right]\right.$ after excluding Lai et $\mathrm{al}^{27}$ ), survival to hospital admission (OR $=0.73\left[95 \% \mathrm{Cl} 0.59-0.90, p=0.0085, \mathrm{I}^{2}=\right.$ $80 \%$ ] after excluding Mathew et $\left.\mathrm{al}^{36}\right)$, survival to hospital discharge $(\mathrm{OR}=0.57[95 \% \mathrm{Cl} 0.45-0.71, \mathrm{p}=$ $\left.0.0003, \mathrm{I}^{2}=51 \%\right]$ after excluding Sultanian et $\left.\mathrm{a}^{38}\right)$, shockable rhythm $(\mathrm{OR}=0.77[95 \% \mathrm{Cl} 0.67-0.89, \mathrm{p}=$ $\left.0.0017, \mathrm{I}^{2}=57 \%\right]$ after excluding Lai et $\left.\mathrm{al}^{27}\right)$, medical etiology $\left(\mathrm{OR}=1.02\left[95 \% \mathrm{Cl} 0.76-1.38, \mathrm{p}=0.8768, \mathrm{I}^{2}\right.\right.$ $=83 \%]$ after excluding Sultanian et $\left.\mathrm{al}^{38}\right)$, traumatic etiology $\left(\mathrm{OR}=0.77\left[95 \% \mathrm{Cl} 0.48-1.24, \mathrm{p}=0.2172, \mathrm{I}^{2}=\right.\right.$ 62\%] after excluding Baldi et $\mathrm{al}^{24}$ ).

\subsection{Publication Bias}

The funnel plots were based on chosen primary and secondary outcomes with the highest number of studies (mortality and ROSC respectively). These plots revealed no visual asymmetry, hence suggesting the absence of publication bias (Supplemental Fig. 1). This was supported by non-significant Egger's regression tests $(p=0.09128$ and $p=0.750$ respectively $)$.

\section{Discussion}

In this systematic review and meta-analysis, the COVID-19 pandemic was associated with a significant $39.5 \%$ increase in pooled incidence and higher CFR with nearly doubled odds of mortality among cases. There was a decreased rate of shockable rhythm as the initial presenting rhythm, a decrease in rates of 
ROSC, survival to hospital admission, and survival to hospital discharge, and an increase in field TOR rate.

The increased incidence during the pandemic was consistently reported in all studies, except in Paoli et al's $^{29}$, which was inconclusive for change in incidence. Paoli et al's ${ }^{29}$ research letter was limited by a short follow-up period and resultant small sample size accumulated, which could have resulted in a false negative effect on incidence. The increase in pooled incidence was sizeable at $39.5 \%$ which implied a substantially increased disease burden. The reasons for this increase were not explicitly investigated in any of these studies. It was likely that the increased population risk was multifactorial and mediated through both direct and indirect pathways. The direct impacts of the coronavirus included that of severe respiratory failure leading to hypoxic causes of arrest, venous thromboembolism, and also through cardiac involvement manifesting as myocarditis, acute coronary thrombosis, and arrhythmias. ${ }^{43,44}$

The same increase in incidence was observed in countries that had successfully limited the community spread of the COVID-19 virus during the study period, such as Singapore and Victoria, Australia. ${ }^{7,35}$ One of these indirect effects may be attributed to changes in health-seeking behavior, such as patients being reluctant to seek help for acute symptoms until the untreated illness progresses to a severe stage and manifests as OHCA. ${ }^{12,45,46}$ There were reports of delayed presentations for acute myocardial infarction and heart failure during the pandemic reported around the world. ${ }^{47,48}$ In other cases, the disruption (or deprioritization) of "non-essential" health services provision during the pandemic may have adversely affected the ongoing management of chronic disease, leading to increased individual-level risk. ${ }^{6,49}$ In addition, independent of the reluctance to seek help, patients with severe acute illness may have deteriorated due to reduced access to emergency health services, such as emergency department overcrowding and delayed ambulance response time. ${ }^{17,19,50}$ The relative importance of each causal pathway is likely to differ between cities, as our study found that OHCA of asphyxial etiology was increased in some, but not all studies.

The second significant finding was that of worsened clinical outcomes for OHCA during the pandemic. Of note, the pooled odds of mortality were double those of historical controls. We postulate that this was attributed to pandemic-related changes affecting each link in the chain of survival. ${ }^{51,52}$ Social distancing measures across the world may have inadvertently reduced the probability that an arrest occurred in a public setting, in the proximity of a bystander, to deliver bystander cardiopulmonary resuscitation, early defibrillation, early recognition, and early activation of emergency medical services (EMS). ${ }^{53}$ Concerns of contracting a communicable virus also adversely affected the willingness-to-help. ${ }^{54}$ Finally, the ability of emergency health services (both pre-hospital and hospital) to deliver high quality care may have been compromised due to immensely stretched resources at a time when extensive resources were diverted to care for COVID-19 patients. ${ }^{19}$ Of interest was the finding that there was substantial heterogeneity reflecting that the effects of the pandemic on OHCA outcomes differed greatly between studies. Some cities, such as London, UK, experienced little increase in mortality despite a large increase in incidence. ${ }^{8}$ 
This was possibly a reflection of differences in emergency preparedness and surge capacity in emergency health services and culture.

The reason for increased field TOR found in our study was most likely directly related to the decreased rates of ROSC and shockable rhythm as the initial presenting rhythm, which are two of three criteria of the Basic Life Support TOR rule. ${ }^{55}$ The third criteria is EMS witnessed arrest, and although this event characteristic was not reported in the studies, it is likely that the rates of these arrests decreased, due to overwhelmed ambulance resources as well as the pandemic requirement for revised ambulance protocols. Another reason could be the delay of patient interventions as medical professionals are required to don personal protective equipment (PPE) at the scene prior to resuscitation. ${ }^{18}$

We reported a decreased proportion of shockable rhythm during the pandemic. As cardiac-etiology OHCAs are more likely to present with shockable rhythm, this finding may imply a shift in underlying etiology to non-cardiac etiologies. Our meta-analysis suggests that there was a significant shift to an asphyxial etiology of cardiac arrest during the pandemic. However, this finding should be reviewed with the caution that there are substantial variations in classifying etiologies used by each study.

There are several implications of our findings. The large impact of indirect effects of a viral pandemic on the epidemiology of other diseases has tremendous public health significance. The need to sensibly maintain a functional healthcare system to serve non-COVID health needs cannot be understated. While immense public and political attention are given to performance indicators for COVID-19 cases, health systems need to prevent deterioration in the care of other diseases. When pandemics become protracted, this impact may progressively worsen and become multifactorial. This necessitates that health systems operate with some excess capacity during non-pandemic times, through the pursuit of technologies and policies that increase efficiency. In the case of OHCA, which is resource-intensive to care for (in terms of requirements for rapid response, intensive care unit beds, and ventilators), these patients compete directly with COVID-19 patients for many of the same resources. The need for pre-emptively planned and rehearsed operating protocols for emergency care systems (both pre-hospital and hospital) in a pandemic is paramount for high performance during such times. These include stockpiling of PPE, procedural confidence when encumbered by PPE, and clear policies on field TOR. There should also be clearly defined triggers for a health system to enter disaster mode, when the focus switches from "saving everyone" to "doing the best for the most". The crucial need for pertinent public health messaging to appropriately utilize emergency care services is markedly exemplified in such pandemics.

Several limitations of our study need acknowledgement. Firstly, all studies utilized a before-after comparison design. This design is inherently susceptible to secular trends leading to biased estimates. For example, the increase in incidence found could simply be a reflection of an underlying increasing trend (such as an aging population) which would have been observed even without a pandemic. This means that the effect sizes could be overestimated. Each study defined the COVID-19 and pre-COVID-19 time periods differently. The pandemic is likely to exert varying epidemiological pressures over time, and the effect sizes estimated are dependent on the cut-offs chosen. Heterogeneity in cut-off definition 
causes contamination of exposure, which often has the effect of under-estimating effect sizes. The included studies originated from regions with existing OHCA registries, which meant that lower-income countries without established OHCA surveillance mechanisms were under-represented. Our study conclusions are hence not generalizable to lower-income countries, which may be disproportionately affected by the pandemic. We were unable to ascertain the quality of data collected during the pandemic period. The pandemic period may have affected surveillance and data quality processes. ${ }^{56}$ Under-capture of cases during the pandemic period would lead to consequent under-estimation of incidence. There was moderate-to-high statistical heterogeneity in most random-effects models constructed. This was likely attributed to the intrinsic differences in population demographics among included studies. Finally, one cannot discount the possibility that the observations were partly artefactual, specifically from publication bias which favored the publication of positive findings. This is a concern as there has been a proliferation of studies with high risk of bias owing to the exuberance of researchers and hastened editorial process. ${ }^{57}$ However, our formal assessment for publication bias revealed no evidence of this among the included studies.

\section{Conclusion}

The COVID-19 pandemic was associated with significant changes in OHCA epidemiology. Compared to the pre-pandemic period, the pandemic period was associated with increased incidence and CFR of OHCA. There were corresponding changes in intermediate outcomes and clinical characteristics.

\section{Declarations}

\section{Availability of Data and Materials}

The datasets used and/or analyzed during the current study are available from the corresponding author on reasonable request.

\section{Ethics Declarations}

Ethics Approval and Consent to Participate

Not applicable.

\section{Consent for Publication}

Not applicable.

\section{Competing Interests}

The authors declare that they have no competing interests.

\section{Funding}


All authors declare no sources of funding for this study.

\section{Author Contributions}

AFWH conceptualized and designed the study. SET and YM performed the literature search. SET, YM, and DTJH assessed the eligibility of each study and acquired the data, which were supervised by AFWH. SET, $\mathrm{YM}, \mathrm{NL}$, and AFWH performed the statistical analysis and were involved in the interpretation of analytic results. SET, YM, and AFWH drafted the article. All authors made critical revisions of the original article and approved the final version for submission to the journal.

\section{Acknowledgements}

We acknowledge the assistance of Mr. Daryl Jimian Lin in data collection and administrative support which was crucial to the completion of this study.

The corresponding author acknowledges that (1) persons who have made substantial contributions to the research and/or manuscript (e.g. study conduct, data collection, data analyses, and writing or editing assistance), but who do not fulfil authorship criteria, are named with their specific contributions in the "Acknowledgements" section of the manuscript; (2) all persons named in the "Acknowledgements" section have provided the corresponding author with permission to be named in the manuscript.

\section{Abbreviations}

\section{COVID-19}

Coronavirus disease 2019

\section{SARS-CoV-2}

Severe acute respiratory syndrome coronavirus 2

\section{OHCA}

Out-of-hospital cardiac arrest

\section{CFR}

Case fatality rate

\section{TOR}

Termination of resuscitation

\section{ROSC}

Return of spontaneous circulation

\section{PRISMA}

Preferred Reporting Items for Systematic Reviews and Meta-Analyses

\section{PROSPERO}

Prospective Register of Systematic Reviews

OR

Odds ratio

Cl 
Confidence interval

PPE

Personal protective equipment

EMS

Emergency medical services

\section{References}

1. Wang C, Horby PW, Hayden FG, Gao GF. A novel coronavirus outbreak of global health concern. The Lancet. 2020;395:470-3. doi:10.1016/S0140-6736(20)30185-9.

2. World Health Organisation. Rolling updates on coronavirus disease (COVID-19). n.d.

3. Logroscino G, Beghi E. Stroke epidemiology and COVID-19 pandemic. Curr Opin Neurol. 2021;34:310. doi:10.1097/WCO.0000000000000879.

4. Myat A, Song K-J, Rea T. Out-of-hospital cardiac arrest: current concepts. Lancet Lond Engl. 2018;391:970-9. doi:10.1016/S0140-6736(18)30472-0.

5. Nadarajan GD, Tiah L, Ho AFW, Azazh A, Castren MK, Chong SL, et al. Global resuscitation alliance utstein recommendations for developing emergency care systems to improve cardiac arrest survival. Resuscitation. 2018;132:85-9. doi:10.1016/j.resuscitation.2018.08.022.

6. Marijon E, Karam N, Jost D, Perrot D, Frattini B, Derkenne C, et al. Out-of-hospital cardiac arrest during the COVID-19 pandemic in Paris, France: a population-based, observational study. Lancet Public Health. 2020;5:e437-43. doi:10.1016/S2468-2667(20)30117-1.

7. Ball J, Nehme Z, Bernard S, Stub D, Stephenson M, Smith K. Collateral damage: Hidden impact of the COVID-19 pandemic on the out-of-hospital cardiac arrest system-of-care. Resuscitation. 2020;156:157-63. doi:10.1016/j.resuscitation.2020.09.017.

8. Fothergill RT, Smith AL, Wrigley F, Perkins GD. Out-of-Hospital Cardiac Arrest in London during the COVID-19 pandemic. Resusc Plus. 2021;5:100066. doi:10.1016/j.resplu.2020.100066.

9. Shi S, Qin M, Shen B, Cai Y, Liu T, Yang F, et al. Association of Cardiac Injury With Mortality in Hospitalized Patients With COVID-19 in Wuhan, China. JAMA Cardiol. 2020;5:802-10. doi:10.1001/jamacardio.2020.0950.

10. Guo T, Fan Y, Chen M, Wu X, Zhang L, He T, et al. Cardiovascular Implications of Fatal Outcomes of Patients With Coronavirus Disease 2019 (COVID-19). JAMA Cardiol. 2020;5:811-8. doi:10.1001/jamacardio.2020.1017.

11. Xiao H, Dai X, Wagenaar BH, Liu F, Augusto O, Guo Y, et al. The impact of the COVID-19 pandemic on health services utilization in China: Time-series analyses for 2016-2020. Lancet Reg Health - West Pac 2021;9. doi:10.1016/j.lanwpc.2021.100122.

12. Wessler BS, Kent DM, Konstam MA. Fear of Coronavirus Disease 2019-An Emerging Cardiac Risk. JAMA Cardiol. 2020;5:981-2. doi:10.1001/jamacardio.2020.2890. 
13. Baldi E, Bertaia D, Savastano S. Mouth-to-mouth: an obstacle to cardiopulmonary resuscitation for lay-rescuers. Resuscitation. 2014;85:e195-6. doi:10.1016/j.resuscitation.2014.10.001.

14. Garcia S, Albaghdadi MS, Meraj PM, Schmidt C, Garberich R, Jaffer FA, et al. Reduction in STSegment Elevation Cardiac Catheterization Laboratory Activations in the United States During COVID-19 Pandemic. J Am Coll Cardiol. 2020;75:2871-2. doi:10.1016/j.jacc.2020.04.011.

15. Migliore F, Zorzi A, Gregori D, Del Monte A, Falzone PV, Verlato R, et al. Urgent Pacemaker Implantation Rates in the Veneto Region of Italy After the COVID-19 Outbreak. Circ Arrhythm Electrophysiol. 2020;13:e008722. doi:10.1161/CIRCEP.120.008722.

16. Scquizzato T, Olasveengen TM, Ristagno G, Semeraro F. The other side of novel coronavirus outbreak: Fear of performing cardiopulmonary resuscitation. Resuscitation. 2020;150:92-3. doi:10.1016/j.resuscitation.2020.03.019.

17. Grunau B, Helmer J, Lee S, Acker J, Deakin J, Armour R, et al. Decrease in emergency medical services utilization during early stages of the COVID-19 pandemic in British Columbia. CJEM. 2021;23:237-41. doi:10.1007/s43678-020-00062-y.

18. Sorbello M, Di Giacinto I, Falcetta S, Greif R. Ventilation and airway management during Cardiopulmonary Resuscitation in COVID-19 era. Resuscitation. 2020;153:35-6. doi:10.1016/j.resuscitation.2020.05.043.

19. Zangrillo A, Beretta L, Silvani P, Colombo S, Scandroglio AM, Dell'Acqua A, et al. Fast reshaping of intensive care unit facilities in a large metropolitan hospital in Milan, Italy: facing the COVID-19 pandemic emergency. Crit Care Resusc J Australas Acad Crit Care Med. 2020;22:91-4.

20. Page MJ, Moher D, Bossuyt PM, Boutron I, Hoffmann TC, Mulrow CD, et al. PRISMA 2020 explanation and elaboration: updated guidance and exemplars for reporting systematic reviews. BMJ. 2021;372:n160. doi:10.1136/bmj.n160.

21. Ouzzani M, Hammady H, Fedorowicz Z, Elmagarmid A. Rayyan-a web and mobile app for systematic reviews. Syst Rev. 2016;5:210. doi:10.1186/s13643-016-0384-4.

22. Wells G, Shea B, O'Connell D, Peterson je, Welch V, Losos M, et al. The Newcastle-Ottawa Scale (NOS) for Assessing the Quality of Non-Randomized Studies in Meta-Analysis. á⿴囗 2000;á⿴囗.

23. Baert V, Jaeger D, Hubert H, Lascarrou J-B, Debaty G, Chouihed T, et al. Assessment of changes in cardiopulmonary resuscitation practices and outcomes on 1005 victims of out-of-hospital cardiac arrest during the COVID-19 outbreak: registry-based study. Scand J Trauma Resusc Emerg Med. 2020;28:119. doi:10.1186/s13049-020-00813-x.

24. Baldi E, Sechi GM, Mare C, Canevari F, Brancaglione A, Primi R, et al. COVID-19 kills at home: the close relationship between the epidemic and the increase of out-of-hospital cardiac arrests. Eur Heart J. 2020;41:3045-54. doi:10.1093/eurheartj/ehaa508.

25. Cho JW, Jung H, Lee MJ, Lee SH, Lee SH, Mun YH, et al. Preparedness of personal protective equipment and implementation of new CPR strategies for patients with out-of-hospital cardiac arrest in the COVID-19 era. Resusc Plus. 2020;3:100015. doi:10.1016/j.resplu.2020.100015. 
26. Elmer J, Okubo M, Guyette FX, Martin-Gill C. Indirect effects of COVID-19 on OHCA in a low prevalence region. Resuscitation. 2020;156:282-3. doi:10.1016/j.resuscitation.2020.08.127.

27. Lai PH, Lancet EA, Weiden MD, Webber MP, Zeig-Owens R, Hall CB, et al. Characteristics Associated With Out-of-Hospital Cardiac Arrests and Resuscitations During the Novel Coronavirus Disease 2019 Pandemic in New York City. JAMA Cardiol. 2020;5:1154-63. doi:10.1001/jamacardio.2020.2488.

28. Rosell Ortiz F, Fernández del Valle P, Knox EC, Jiménez Fábrega X, Navalpotro Pascual JM, Mateo Rodríguez I, et al. Influence of the Covid-19 pandemic on out-of-hospital cardiac arrest. A Spanish nationwide prospective cohort study. Resuscitation. 2020;157:230-40. doi:10.1016/j.resuscitation.2020.09.037.

29. Paoli A, Brischigliaro L, Scquizzato T, Favaretto A, Spagna A. Out-of-hospital cardiac arrest during the COVID-19 pandemic in the Province of Padua, Northeast Italy. Resuscitation. 2020;154:47-9. doi:10.1016/j.resuscitation.2020.06.031.

30. Sayre MR, Barnard LM, Counts CR, Drucker CJ, Kudenchuk PJ, Rea TD, et al. Prevalence of COVID-19 in Out-of-Hospital Cardiac Arrest: Implications for Bystander Cardiopulmonary Resuscitation. Circulation. 2020;142:507-9. doi:10.1161/CIRCULATIONAHA.120.048951.

31. Semeraro F, Gamberini L, Tartaglione M, larussi B, Descovich C, Picoco C, et al. Out-of-hospital cardiac arrest during the COVID-19 era in Bologna: System response to preserve performances. Resuscitation. 2020;157:1-2. doi:10.1016/j.resuscitation.2020.09.032.

32. Chan PS, Girotra S, Tang Y, Al-Araji R, Nallamothu BK, McNally B. Outcomes for Out-of-Hospital Cardiac Arrest in the United States During the Coronavirus Disease 2019 Pandemic. JAMA Cardiol. 2021;6:296-303. doi:10.1001/jamacardio.2020.6210.

33. de Koning ER, Boogers MJ, Bosch J, de Visser M, Schalij MJ, Beeres SLMA. Emergency medical services evaluations for chest pain during first COVID-19 lockdown in Hollands-Midden, the Netherlands. Neth Heart J Mon J Neth Soc Cardiol Neth Heart Found. 2021;29:224-9. doi:10.1007/s12471-021-01545-y.

34. Glober NK, Supples M, Faris G, Arkins T, Christopher S, Fulks T, et al. Out-of-hospital cardiac arrest volumes and characteristics during the COVID-19 pandemic. Am J Emerg Med. 2021;48:191-7. doi:10.1016/j.ajem.2021.04.072.

35. Lim SL, Shahidah N, Saffari SE, Ng QX, Ho AFW, Leong BS-H, et al. Impact of COVID-19 on Out-ofHospital Cardiac Arrest in Singapore. Int J Environ Res Public Health 2021;18. doi:10.3390/ijerph18073646.

36. Mathew S, Harrison N, Chalek AD, Gorelick D, Brennan E, Wise S, et al. Effects of the COVID-19 pandemic on out-of-hospital cardiac arrest care in Detroit. Am J Emerg Med. 2021;46:90-6. doi:10.1016/j.ajem.2021.03.025.

37. Nickles AV, Oostema A, Allen J, O'Brien SL, Demel SL, Reeves MJ. Comparison of Out-of-Hospital Cardiac Arrests and Fatalities in the Metro Detroit Area During the COVID-19 Pandemic With Previous-Year Events. JAMA Netw Open. 2021;4:e2032331-1. doi:10.1001/jamanetworkopen.2020.32331. 
38. Sultanian P, Lundgren P, Strömsöe A, Aune S, Bergström G, Hagberg E, et al. Cardiac arrest in COVID19: characteristics and outcomes of in- and out-of-hospital cardiac arrest. A report from the Swedish Registry for Cardiopulmonary Resuscitation. Eur Heart J. 2021;42:1094-106. doi:10.1093/eurheartj/ehaa1067.

39. Uy-Evanado A, Chugh HS, Sargsyan A, Nakamura K, Mariani R, Hadduck K, et al. Out-of-Hospital Cardiac Arrest Response and Outcomes During the COVID-19 Pandemic. JACC Clin Electrophysiol. 2021;7:6-11. doi:10.1016/j.jacep.2020.08.010.

40. Berdowski J, Berg RA, Tijssen JGP, Koster RW. Global incidences of out-of-hospital cardiac arrest and survival rates: Systematic review of 67 prospective studies. Resuscitation. 2010;81:1479-87. doi:10.1016/j.resuscitation.2010.08.006.

41. Lin L, Xu C. Arcsine-based transformations for meta-analysis of proportions: Pros, cons, and alternatives. Health Sci Rep. 2020;3:e178. doi:10.1002/hsr2.178.

42. Higgins JPT, Thompson SG, Deeks JJ, Altman DG. Measuring inconsistency in meta-analyses. BMJ. 2003;327:557-60. doi:10.1136/bmj.327.7414.557.

43. Ho JS, Tambyah PA, Ho AF, Chan MY, Sia C-H. Effect of coronavirus infection on the human heart: A scoping review. Eur J Prev Cardiol. 2020;27:1136-48. doi:10.1177/2047487320925965.

44. Akhmerov A, Marbán E. COVID-19 and the Heart. Circ Res. 2020;126:1443-55. doi:10.1161/CIRCRESAHA.120.317055.

45. De Filippo O, D'Ascenzo F, Angelini F, Bocchino PP, Conrotto F, Saglietto A, et al. Reduced Rate of Hospital Admissions for ACS during Covid-19 Outbreak in Northern Italy. N Engl J Med. 2020;383:88-9. doi:10.1056/NEJMc2009166.

46. Sun C, Dyer S, Salvia J, Segal L, Levi R. Worse Cardiac Arrest Outcomes During The COVID-19 Pandemic In Boston Can Be Attributed To Patient Reluctance To Seek Care. Health Aff (Millwood). 2021. 10.1377/hlthaff.2021.00250. doi:10.1377/hlthaff.2021.00250.

47. Erol MK, Kayıkçıoğlu M, Kılıçkap M, Güler A, Yıldırım A, Kahraman F, et al. Treatment delays and inhospital outcomes in acute myocardial infarction during the COVID-19 pandemic: A nationwide study. Anatol J Cardiol. 2020;24:334-42. doi:10.14744/AnatolJCardiol.2020.98607.

48. De L Giuseppe, Monica V, Miha C, Okkels JL, Marija V, Lucian C, et al. Impact of COVID-19 Pandemic on Mechanical Reperfusion for Patients With STEMI. J Am Coll Cardiol. 2020;76:2321-30. doi:10.1016/j.jacc.2020.09.546.

49. De Rosa S, Spaccarotella C, Basso C, Calabrò MP, Curcio A, Filardi PP, et al. Reduction of hospitalizations for myocardial infarction in Italy in the COVID-19 era. Eur Heart J. 2020;41:2083-8. doi:10.1093/eurheartj/ehaa409.

50. Czeisler M, Marynak K, Clarke KEN, Salah Z, Shakya I, Thierry JM, et al. Delay or Avoidance of Medical Care Because of COVID-19-Related Concerns - United States, June 2020. Morb Mortal Wkly Rep. 2020;69:1250-7. doi:10.15585/mmwr.mm6936a4.

51. Cummins RO, Ornato JP, Thies WH, Pepe PE. Improving survival from sudden cardiac arrest: the "chain of survival" concept. A statement for health professionals from the Advanced Cardiac Life 
Support Subcommittee and the Emergency Cardiac Care Committee. American Heart Association Circulation. 1991;83:1832-47. doi:10.1161/01.cir.83.5.1832.

52. Deakin CD. The chain of survival: Not all links are equal. Resuscitation. 2018;126:80-2. doi:10.1016/j.resuscitation.2018.02.012.

53. Grunau B, Bal J, Scheuermeyer F, Guh D, Dainty KN, Helmer J, et al. Bystanders are less willing to resuscitate out-of-hospital cardiac arrest victims during the COVID-19 pandemic. Resusc Plus. 2020;4:100034-4. doi:10.1016/j.resplu.2020.100034.

54. Couper K, Taylor-Phillips S, Grove A, Freeman K, Osokogu O, Court R, et al. COVID-19 in cardiac arrest and infection risk to rescuers: A systematic review. Resuscitation. 2020;151:59-66. doi:10.1016/j.resuscitation.2020.04.022.

55. Morrison LJ, Visentin LM, Kiss A, Theriault R, Eby D, Vermeulen M, et al. Validation of a Rule for Termination of Resuscitation in Out-of-Hospital Cardiac Arrest. N Engl J Med. 2006;355:478-87. doi:10.1056/NEJMoa052620.

56. Celentano DD, Szklo M, Leon G. The Occurrence of Disease: I. Disease Surveillance and Measures of Morbidity. Gordis Epidemiology. 6th ed. Elsevier; 2018.

57. Raynaud M, Zhang H, Louis K, Goutaudier V, Wang J, Dubourg Q, et al. COVID-19-related medical research: a meta-research and critical appraisal. BMC Med Res Methodol. 2021;21:1. doi:10.1186/s12874-020-01190-w.

\section{Supplementary Materials}

Appendix I - Expanded Methods

Online-only Supplemental Tables

Online-only Supplemental Figures

Online-only Supplemental Data

\section{Figures}




\section{Identification of studies via databases and registers}

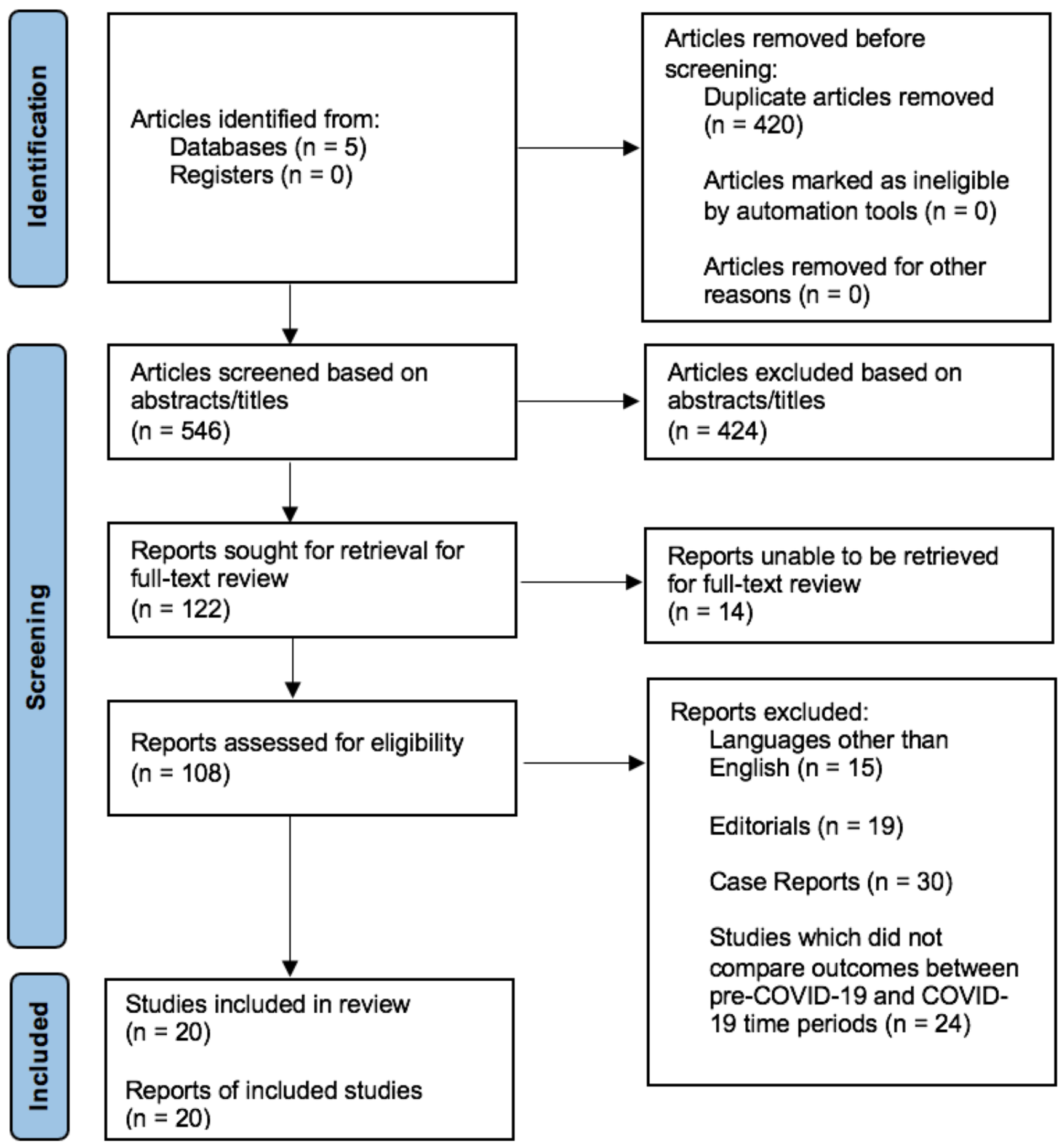

Figure 1

PRISMA-P 2020 Flow Diagram for Study Selection 
(A)

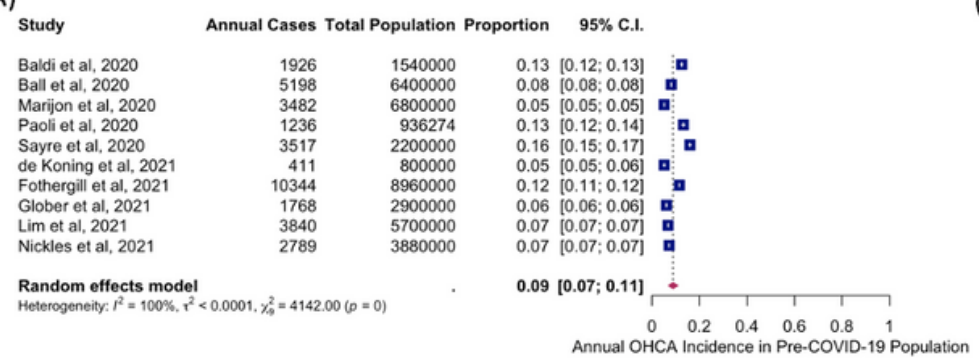

(C)

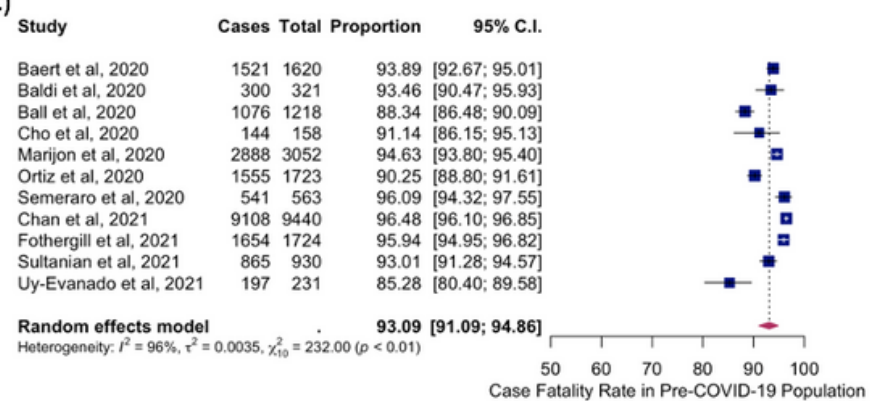

(B)

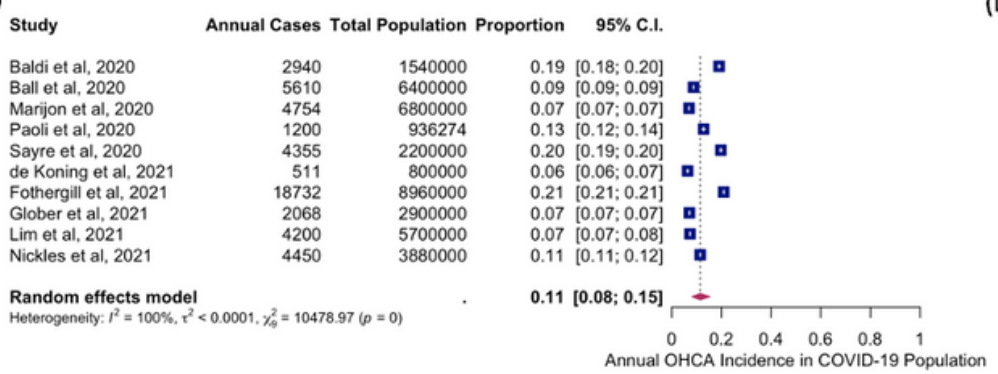

(D)

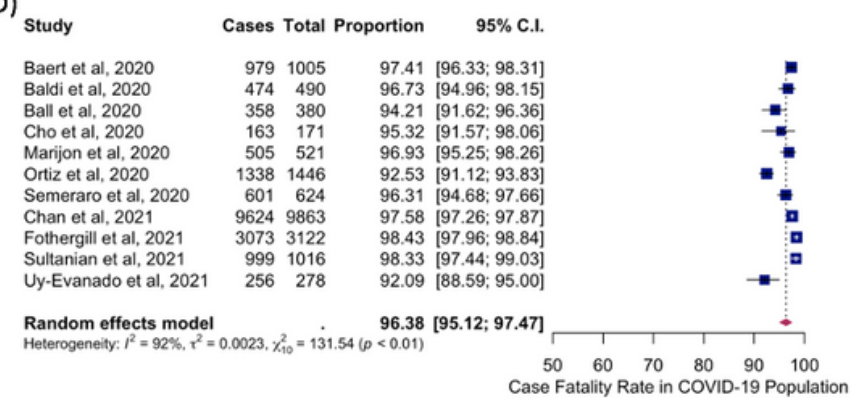

Figure 2

Forest Plots of Estimates from Meta-Analysis of Proportions - (A) Annual OHCA Incidence in Pre-COVID19 Time Period (B) Annual OHCA Incidence in COVID-19 Time Period (C) Case Fatality Rate in Pre-COVID19 Time Period (D) Case Fatality Rate in COVID-19 Time Period COVID-19, coronavirus disease 2019; OHCA, out-of-hospital cardiac arrest

\section{Study}

Baert et al, 2020

Baldi et al, 2020

Ball et al, 2020

Cho et al, 2020

Marijon et al, 2020

Ortiz et al, 2020

Semeraro et al, 2020

Chan et al, 2021

Fothergill et al, 2021

Sultanian et al, 2021

Uy-Evanado et al, 2021
Covid-19 Pre-Covid-19

Events Total Events

$\begin{array}{llll}979 & 1005 & 1521 & 1620\end{array}$

$\begin{array}{llll}474 & 490 & 300 & 321\end{array}$

$\begin{array}{llll}358 & 380 & 1076 & 1218\end{array}$

$\begin{array}{llll}163 & 171 & 144 & 158\end{array}$

$505 \quad 521$

13381446

$601 \quad 624$

96249863

$3073 \quad 3122$

9991016

$256 \quad 278$

$2888 \quad 3052$

1555

541563

91089440

1654

865

197

18916

Total $(95 \% \mathrm{Cl})$

Prediction interval

Heterogeneity: $\mathrm{Tau}^{2}=0.0963 ; \mathrm{Chi}^{2}=30.69, \mathrm{df}=10(\mathrm{P}<0.01) ; \mathrm{I}^{2}=67 \%$

Test for overall effect: $t_{10}=5.87(P=0.0002)$

Odds Ratio

Weight $\mathrm{MH}$, Random, $95 \% \mathrm{Cl}$

$9.7 \%$

$2.45[1.58 ; 3.80]$

$6.7 \% \quad 2.07[1.07 ; 4.04]$

$9.4 \% \quad 2.15[1.35 ; 3.42]$

$4.7 \% \quad 1.98[0.81 ; 4.86]$

$8.5 \%$

$12.6 \%$

$7.6 \%$

$13.8 \%$

$10.8 \%$

$8.3 \%$

$231 \quad 7.9 \%$

$20980100.0 \%$

$1.95[1.51 ; 2.51]$

$[0.92 ; 4.12]$

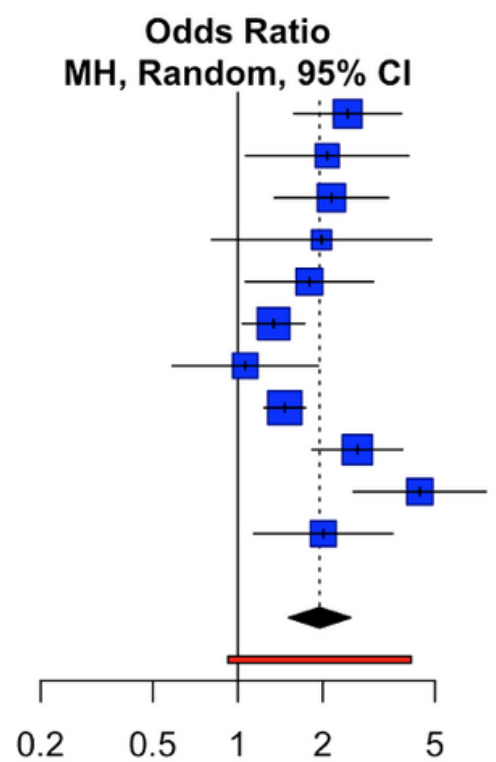

\section{Figure 3}

Forest Plot of Reported Estimates for the Primary Outcome of Mortality Among Patients with Out-ofHospital Cardiac Arrest 

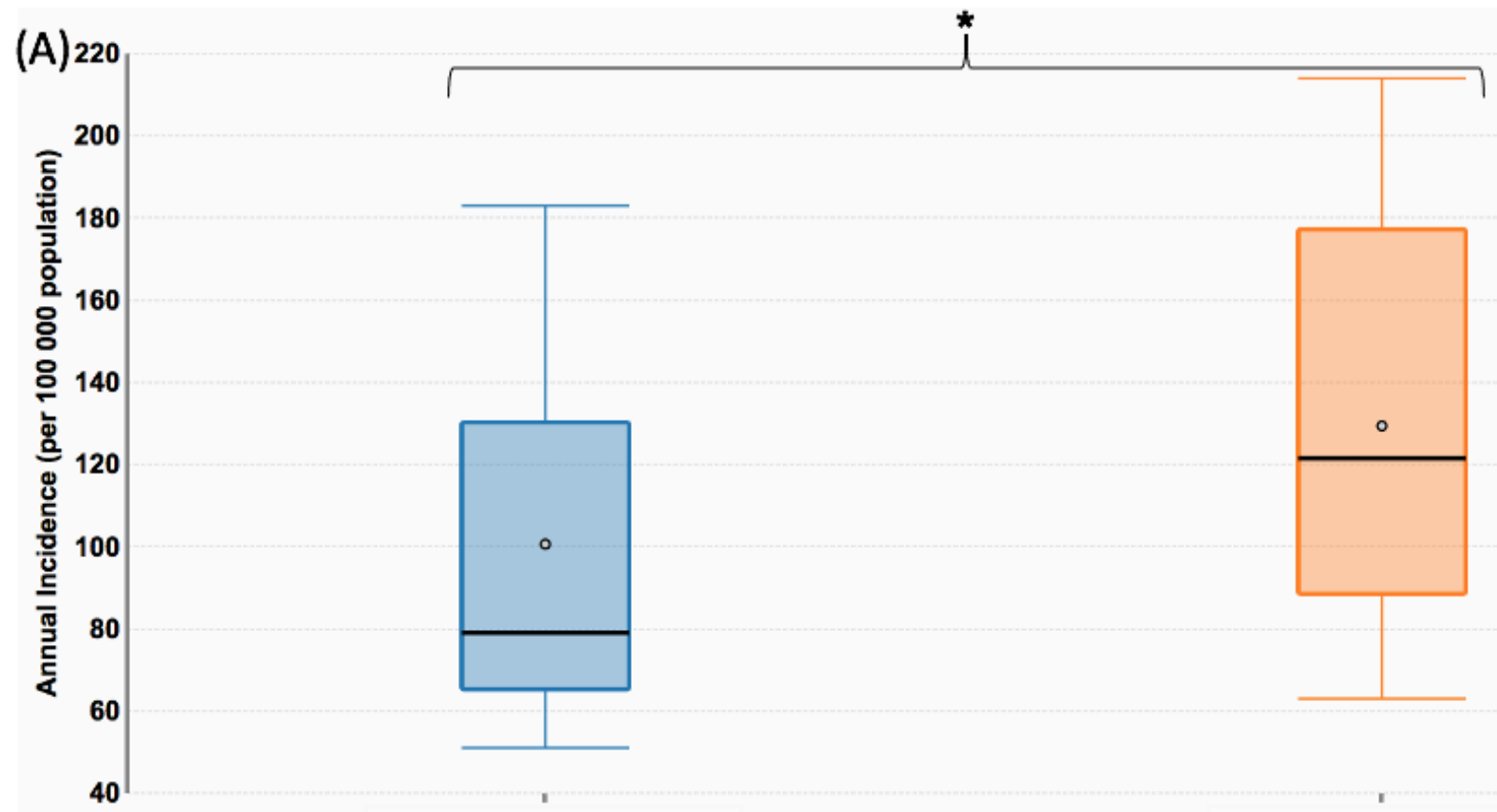

Pre-Covid-19

Covid-19

(B)
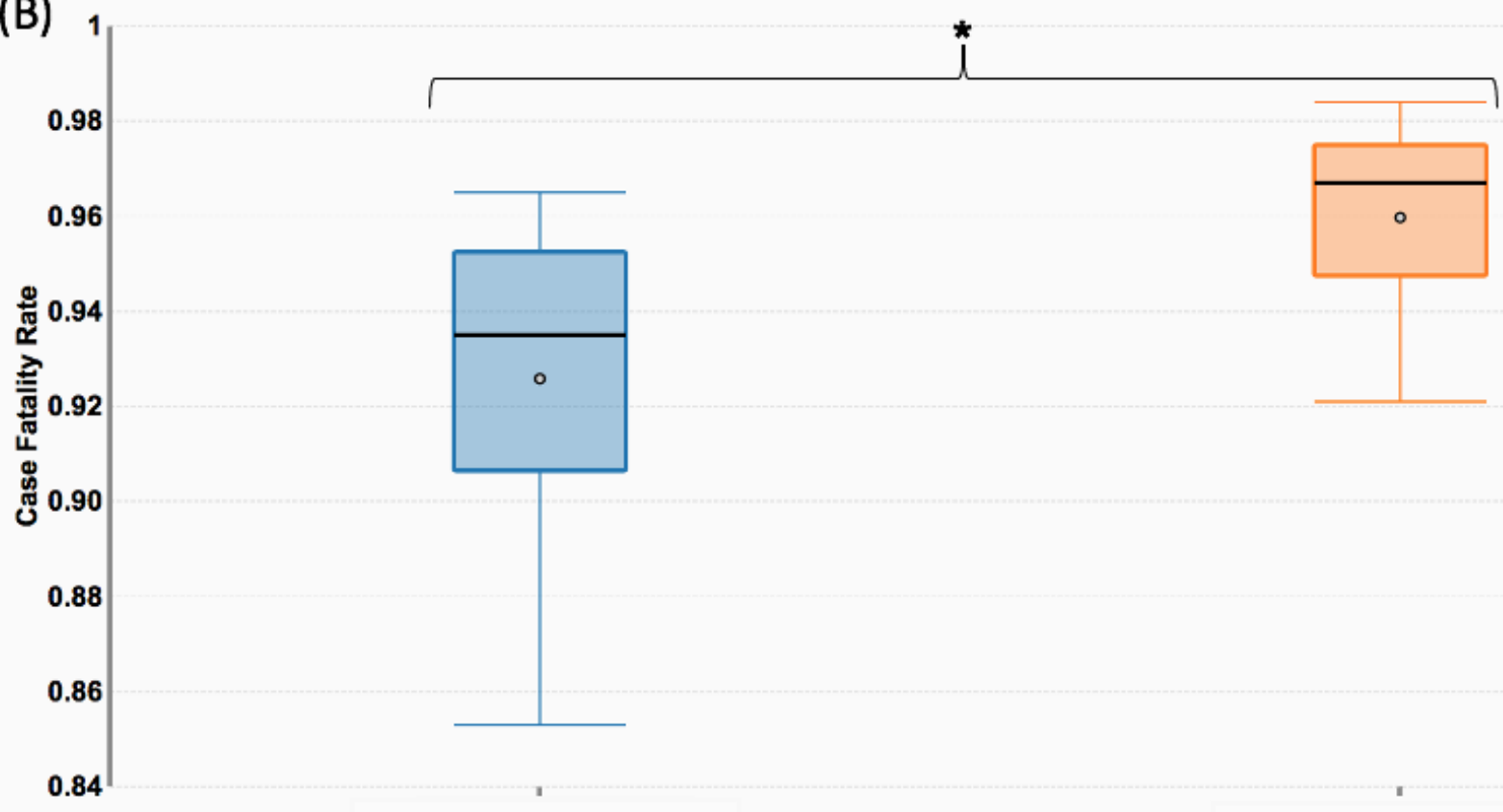

Pre-Covid-19

Covid-19

Figure 4

Box Plots Stratifying Estimates for Pre-Covid-19 and COVID-19 Time Periods for (A) Annual OHCA Incidence (B) Case Fatality Rate. Two-proportions z-tests were statistically significant $(p<0.001)$ for both outcomes, as represented by asterisks (*). COVID-19, coronavirus disease 2019; OHCA, out-of-hospital cardiac arrest 
(A)

Study

Baldi et al, 2020

Lai et al, 2020

Chan et al, 2021

Fothergill et al, 2021

Mathew et al, 202

Total $(95 \% \mathrm{Cl})$

Covid-19 Pre-Covid-19

Odds Ratio

Events Total Events Total Weight MH, Random, 95\% CI

$\begin{array}{llllll}253 & 314 & 156 & 222 & 16.5 \% & 1.75[1.17 ; 2.62]\end{array}$

$200 \quad 291$

$\begin{array}{lll}64 & 180 & 16.7 \%\end{array}$

$3.98[2.69 ; 5.90]$

15589

$11861100.0 \%$

$[0.82 ; 7.40]$

Test for overall effect: $\mathrm{L}_{4}=5.97(\mathrm{P}=0.0040)$ $\begin{array}{lllllll}3566 & 3986 & 999 & 1336 & 22.1 \% & 2.86 & {[2.44 ; 3.36}\end{array}$

$\begin{array}{llllll}5314 & 9863 & 3768 & 9440 & 23.4 \% & 1.76[1.66 ; 1.86]\end{array}$

$2.72[2.23 ; 3.31]$

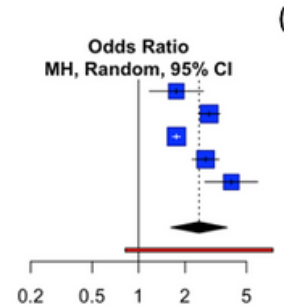

(C) Study Cho et al, 2020 Elmer et al, 2020 Marijon et al, 2020 Ortiz et al, 2020 Paoli et al, 2020
Semeraro et al, 2020
Lim et al, 2021 Mathew et al, 2021 Uy-Evanado et al, 2021

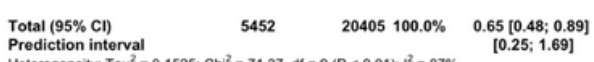

Covid-19 Pre-Covid-19 Odds Ratio 359 1218 Woight MH, Random, 95\% $\begin{array}{llllll}39 & 171 & 49 & 158 & 9.1 \% & 0.66[0.40 ; 1.07]\end{array}$ $\begin{array}{llllllll}67 & 521 & 695 & 3052 & 11.4 \% & 0.50[0.38 ; 0.66\end{array}$

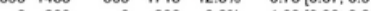
$\begin{array}{rrrrrr}6 & 200 & 6 & 206 & 3.9 \% & 1.03[0.33 ; 3.25\end{array}$

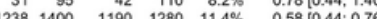

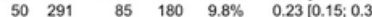
$\begin{array}{rrrrrr}5 & 291 & 85 & 180 & 9.8 \% & 0.23[0.15 ; 0.39 \\ 5 & 278 & 74 & 231 & 10.1 \% & 0.65[0.44 ; 0.96\end{array}$ \begin{tabular}{crrrrr} 
Covid-19 & Pre-Covid-19 & & \multicolumn{1}{c}{ Odds Ratio } \\
Conts & Total Events & Total Weight & MH, Random, 95\% CI \\
195 & 999 & 409 & 1616 & $8.5 \%$ & $0.72[0.59 ; 0.87]$
\end{tabular}

(B) Study

Baert et al, 2020 Baldi et al, 2020 Ball et al, 2020 Cho et al, 2020 Elmer et al, 2020 Lai et al, 2020 Ortiz et al, 2020 Paoli et al, 2020 Semeraro 202020 Semeraro et al, 2020 Fothergill et al, 2021 Fothergill et al, 2021
Lim et al, 2021 Lim et al, 2021 Sultanian et al, 2021 Uy-Evanado et al, 2021 $\begin{array}{rrrrrr}195 & 999 & 409 & 1616 & 8.5 \% & 0.72[0.59 ; 0.87] \\ 27 & 314 & 44 & 222 & 4.6 \% & 0.38[0.23 ; 0.64]\end{array}$ $\begin{array}{llllll}112 & 380 & 416 & 1218 & 7.7 \% & 0.81[0.63 ; 1.03]\end{array}$ $\begin{array}{llllll}8 & 171 & 15 & 158 & 2.3 \% & 0.47[0.19 ; 1.14]\end{array}$ $\begin{array}{llllll}95 & 683 & 1529 & 12252 & 8.1 \% & 1.13[0.91 ; 1.42]\end{array}$ $\begin{array}{llllll}727 & 3989 & 463 & 1336 & 9.0 \% & 0.42[0.37: 0.48\end{array}$ $\begin{array}{llllll}290 & 1433 & 525 & 1718 & 8.8 \% & 0.58[0.49: 0.68]\end{array}$

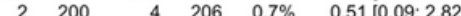
$38 \quad 624 \quad 54 \quad 563 \quad 5.5 \% \quad 0.6110 .40 ; 0.94]$ $2268 \quad 0863 \quad 2813 \quad 9440 \quad 9.6 \% \quad 0.7010 .60 ; 0.75$

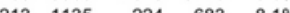

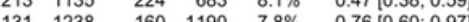
$\begin{array}{lllllll}32 & 291 & 29 & 180 & 4.4 \% & 0.64 & 0.37 \% 1.11]\end{array}$

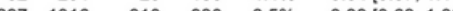
$295 \quad 1016-310 \quad 930-8.5 \% \quad 0.830 .03 \%$

Total $(95 \% \mathrm{Cl})$

22614

31943

$0.65[0.55 ; 0.77]$

Prediction interval

Heterogeneity: $\mathrm{Tau}^{2}=0.0626 ; \mathrm{Chi}^{2}=93.88, \mathrm{df}=14(\mathrm{P}<0.01) ; \mathrm{I}^{2}=85 \%$ $[0.37 ; 1.15]$ Test for overall effect: $t_{14}=-5.60(P<0.0001)$

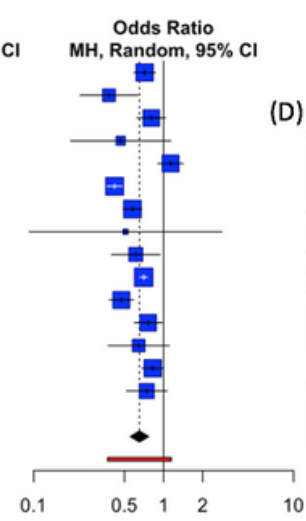

D) Heterogeneity: Tau $^{2}=0.1525 ; \mathrm{Ch}^{2}=71.37$.
Test for overall effect $0.3 .13(\mathrm{P}=0.0122)$ \begin{tabular}{llllll}
554 & 683 & 5950 & 12252 & $12.3 \%$ & 1.14 \\
\hline & $0.98: 1.33$
\end{tabular}

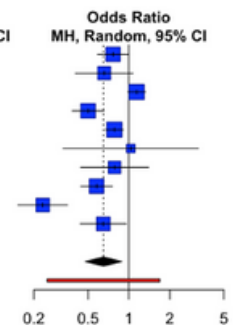
Study
Baert et al, 2020
Baldi et al, 2020 Cho et al, 2020 Marion et al, 2020 Marijon et al, 2020 Semeraro et al, 2020 Chan et al, 2021 Fothergill et al, 2021 Uy-Evanado et al, 2021 Total $(95 \% \mathrm{Cl})$ Covid-19 Pre-Covid-19 Odds Ratio The The Thight MH, Random, 95\% C \begin{tabular}{rrrrrr}
16 & 314 & 21 & 222 & $7.1 \%$ & $0.42[0.27 ; 0.65$ \\
\hline & 314 & $0.26 ; 1.01]$
\end{tabular} $\begin{array}{llrrrr}22 & 380 & 142 & 1218 & 9.5 \% & 0.47[0.29 ; 0.74]\end{array}$ $\begin{array}{rrrrrrr}8 & 171 & 14 & 158 & 5.1 \% & 0.50[0.21: 1.24\end{array}$ $\begin{array}{lllllll}108 & 1446 & 168 & 1723 & 12.2 \% & 0.75 & 0.58 ; 0.96\end{array}$ $\begin{array}{lllllll}23 & 95 & 22 & 110 & 7.2 \% & 1.28[0.66 ; 2.48\end{array}$ $\begin{array}{llllll}239 & 3632 & 332 & 3393 & 13.0 \% & 0.65[0.55 ; 0.77]\end{array}$

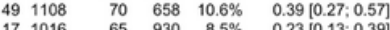
$\begin{array}{lrllll}17 & 1016 & 65 & 930 & 8.5 \% & 0.23[0.13 ; 0.39] \\ 22 & 278 & 34 & 231 & 8.2 \% & 0.50[0.28 ; 0.88]\end{array}$ $9894 \quad 13241100.0 \% \quad 0.52[0.40 ; 0.69]$ [0.22; 1.22$]$ Test for overall effect: $t_{10}=-5.21 \quad(P=0.0004)$

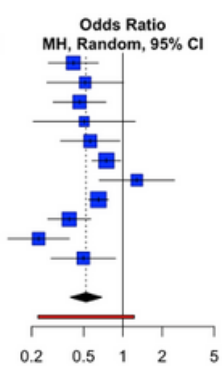

\section{Figure 5}

Forest Plots of Reported Estimates for the Secondary Outcomes - (A) Termination of Resuscitation in the Field (B) Return of Spontaneous Circulation (C) Survival to Hospital Admission (D) Survival to Hospital Discharge

(A) Study

Baert et al, 2020

Baldi et al, 2020

Cho al, 2020

Lai et al, 2020

Marijon et al, 2020

Ortiz et al, 2020

Semeraro et al, 2020

Chan et al, 2021

de Koning et al, 2021

Fothergill et al, 2021

Lim et al, 2021

Mathew et al, 2021

Uy-Evanado et al, 202

Total $(95 \% \mathrm{Cl})$

Heterogeneity: Tau $^{2}=0.0841 ; \mathrm{Chi}^{2}=46.23$,

政

(B)

Study

Baldi et al, 2020

Ball et al, 2020

Elmer et al, 2020

Paoli et al, 2020

Semeraro et al, 2020

Fothergill et al, 2021

Nickles et 2021

Sultanian et al, 2021

Total $(95 \% \mathrm{Cl})$

Prediction interval

Heterogenety $\mathrm{Ta}^{2}=022610 ; \mathrm{Ch}^{2}=117,29$,

Test for overall effect: $t_{8}=-0.56(P=0.5922)$

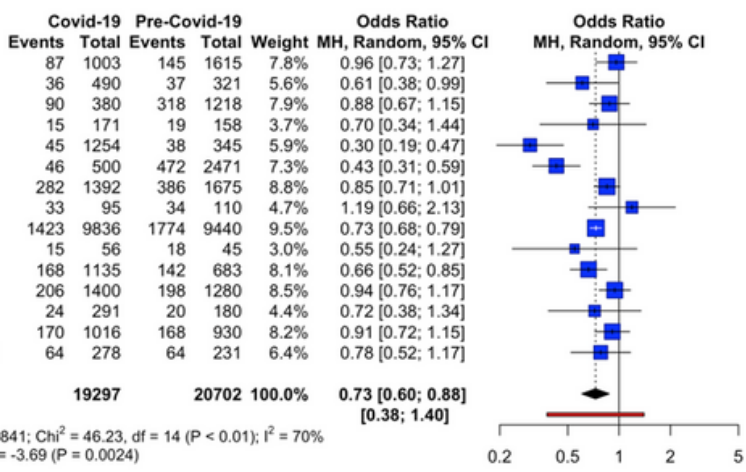

Covid-19 Pre-Covid-19

Odds Ratio Events Total Events Total Weight MH, Random, 95\% Cl $\begin{array}{llllll}465 & 490 & 287 & 321 & 9.5 \% & 2.20[1.29 ; 3.77]\end{array}$ $\begin{array}{llllll}269 & 380 & 929 & 1218 & 11.5 \% & 0.75 \\ {[0.58 ; 0.98}\end{array}$ $\begin{array}{llllll}643 & 683 & 11153 & 12252 & 11.1 \% & 1.58[1.14 ; 2.19]\end{array}$ $\begin{array}{lllll}175 & 200 & 179 & 206 & 9.1 \%\end{array}$ $\begin{array}{rrrrr}7935 & 9863 & 7957 & 9440 & 11.2 \%\end{array}$ $\begin{array}{llllll}1107 & 3122 & 646 & 1724 & 12.0 \%\end{array}$ $\begin{array}{lllll}1854 & 930 & 1162 & 11.8 \%\end{array}$ $1.06[0.59 ; 1.89]$ $0.77[0.71 ; 0.83]$ $0.92[0.81 ; 1.04]$ $1.06[0.88 ; 1.28]$ $1.06[0.88 ; 1.28]$

$$
18232 \quad 27816100.0 \% \quad 0.91[0.60 ; 1.37]
$$
$[0.25 ; 3.25]$

$8(P<0.01) ; I^{2}=93 \%$



(C)



Heterogeneity: Tau $^{2}=0.2173 ; \mathrm{Chi}^{2}=19.90$,
Test for overall effect: $\mathrm{t}_{6}=-1.87(\mathrm{P}=0.1108)$
Covid-19 Pre-Covid-19

Odds Ratio
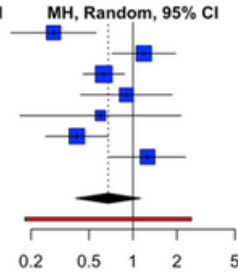

\section{Figure 6}

Forest Plots of Reported Estimates for Clinical Characteristics of Patients with Out-of-Hospital Cardiac Arrest - (A) Shockable Rhythm (B) Medical Etiology (C) Traumatic Etiology (D) Asphyxial Etiology 


\section{Supplementary Files}

This is a list of supplementary files associated with this preprint. Click to download.

- CriticalCareSupplementalMaterialsUpdated.docx 